\title{
Chiral Iron(II) and Cobalt(II) Complexes with Biphenyl-Bridged Bis(pyridylimine) Ligands - Syntheses, Structures and Reactivities
}

\author{
Christoph Vedder, ${ }^{[a]}$ Frank Schaper ${ }^{[a]}$ Hans-Herbert Brintzinger, ${ }^{*[a]}$ Mika Kettunen, ${ }^{[b]}$ \\ Sebastian Babik, ${ }^{[\mathrm{c}]}$ and Gerhard Fink ${ }^{[\mathrm{c}]}$
}

Keywords: Iron(II) / Cobalt(II) / Bianiline / Pyridylimine

A new class of iron(II) and cobalt(II) complexes with neutral, tetradentate bis(pyridylimine) chelate ligands bridged by a chiral 6,6'-dimethylbiphenyl backbone has been synthesized. Their dihalogen derivatives gave spectral, magnetic and X-ray diffraction results in agreement with a $\mathrm{C}_{2}$-symmetric, approximately octahedral geometry with cis-positioned halide ligands and high-spin d-electron configuration. ${ }^{1} \mathrm{H}$ NMR signals of these paramagnetic complexes were assigned by correlating line widths with reciprocal proton-metal distances. Methyl substitution in 6-position of the pyridyl

\section{Introduction}

Complexes of late transition metals such as $\mathrm{Pd}, \mathrm{Ni}, \mathrm{Fe}$, or Co are interesting targets for olefin polymerization catalysis, ${ }^{[1,2]}$ none the least since these catalysts are relatively tolerant towards polar substrates and might thus allow copolymerization of $\alpha$-olefins with polar monomers. ${ }^{[3]}$ Ironbased eatalysts in particular have shown activities for ethene polymerization which are comparable to those of the most active group(IV) metallocene catalysts. The excellent stereoselectivity of metallocene-catalyzed propene polymerization, ${ }^{[4]}$ however, is still lacking for late transition metal catalysts. Low-temperature polymerizations have afforded polypropene with only partially syndiotactic or isotactic microstructures induced by chain-end stereocontrol. ${ }^{[5]}$

Most iron- or cobalt-based polymerization eatalysts employ symmetric tridentate pyridyldiimine ligands, which form $C_{2 v}$-symmetric bipyramidal complex species with homotopic coordination sites (Scheme 1). ${ }^{[1,2 c]}$ Enantiotopic coordination sites, as required for olefin insertion under catalytic-site control, might be obtained by use of axially chiral, tetradentate ligands, from which $C_{2}$-symmetric octahedral complexes would be generated on coordina-

[a] Fachbereich Chemie, Universität Konstanz, 78457 Konstanz, Germany Fax: +49-7531-883137

E-mail: hans.brintzinger@uni-konstanz.de

[b] Laboratory of Inorganic Chemistry, University of Helsinki, 00014 Helsinki, Finland

[c] Max-Planck-Institut für Kohlenforschung, 45470 Mülheim/Ruhr, Germany rings lead to a different, presumably square-pyramidal coordination geometry under dissociation of one chloride ion. Fe $\mathrm{F}^{\mathrm{II}}$ dimethyl and diisocyanide derivatives were shown to have low-spin configuration and $C_{1}$-symmetric geometry. With respect to MAO-activated olefin polymerization, significant catalytic activities were reproducibly obtained only under conditions, where the original complex structure was degraded.

tion to $\mathrm{MX}_{2}$ (Scheme 1). Chiral complexes with two N ligand atoms have previously been applied in enantioselective homogeneous catalysis. ${ }^{[6]}$ Here we report on the synthesis of chiral $\mathrm{Fe}^{\mathrm{II}}$ and $\mathrm{Co}^{\mathrm{II}}$ complexes with $C_{2}$-symmetric, bianiline-bridged tetradentate nitrogen ligands, and on the properties of these complexes in homogeneous olefin polymerization.
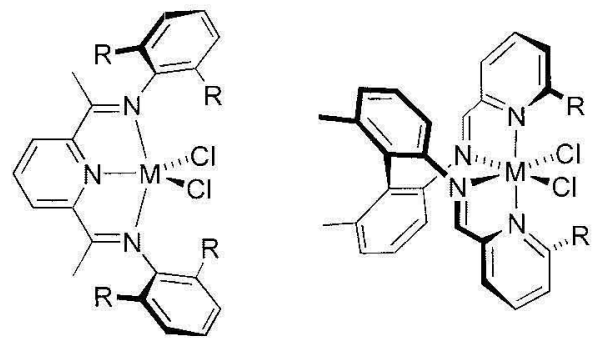

Scheme 1. Pyridyldiimine complexes with $C_{2 v}$ symmetry (left) and biphenyl-bridged bis(pyridylimine) complexes with axial $C_{2}$ symmetry (right)

\section{Results and Discussion}

\section{Ligand Syntheses}

The neutral, potentially tetradentate ligands $N, N^{\prime}$-(biphenyl-2,2'-diyl)bis(2-pyridylmethyl)diimine (1), and $N, N^{\prime}$ (6,6'-dimethylbiphenyl-2,2'-diyl)bis[(6-R' -2 -pyridyl) methyl]diimine $\left[\mathrm{R}^{\prime \prime}=\mathrm{H}(2)\right.$, $\left.\mathrm{Me}(3)\right]$, were prepared by condensation of the known $N, N^{\prime}$-(biphenyl-2,2'-diyl)diamines 4 and $5,{ }^{[7]}$ with the appropriate heteroaromatic aldehyde in 
ethanol at room temperature [Equation (1)]. Ligand 1 was reacted directly, without prior isolation, with iron(II) chloride (vide infra). Reaction of $\mathbf{5}$ with 2-acetylpyridine, be it in ethanol, methanol or dichloromethane with catalytic amounts of acetic, formic or hydrochloric acid, or in benzene over molecular sieves or in diethyl ether/pentane mixtures in the presence of excess $\mathrm{TiCl}_{4}$, did not afford the desired ligand $\mathbf{6}$. Refluxing a toluene solution of 5 and 2acetylpyridine with a catalytic amount of $p$-toluenesulfonic acid in a Dean-Stark apparatus, however, yielded after three days a mixture which contained, apart from the starting materials, $N, N^{\prime}$-(6, $6^{\prime}$-dimethylbiphenyl-2,2' -diyl)bis[1(2-pyridyl)ethane]diimine (6), in ca. $45 \%$ yield as determined by ${ }^{1} \mathrm{H}$ NMR spectroscopy. This reaction mixture was used without purification for further complex syntheses.

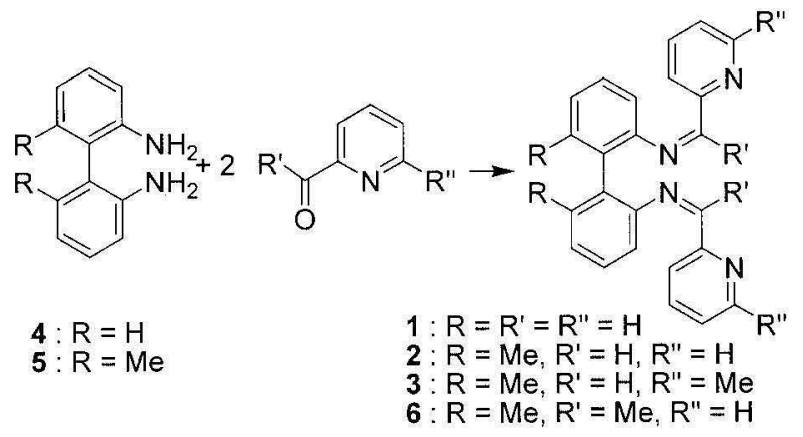

\section{Complex Syntheses, Structures, and Spectroscopic Properties}

Reaction of $\mathrm{FeCl}_{2}$ or $\mathrm{FeBr}_{2}$ with the dipyridyldiimine ligands 1, 2, or $\mathbf{6}$ in THF afforded, after evaporation of solvent and extraction with $\mathrm{CH}_{2} \mathrm{Cl}_{2}$, the blue to turquoise iron(II) complexes 7-10 [Equation (2)] ${ }^{[8]}$ Since 7-10 were found to be insoluble in non-chlorinated solvents, excess ligand (and starting materials of the ligand synthesis in the case of 6) was removed by washing with diethyl ether and pentane to yield analytically and spectroscopically pure products. The light brown cobalt(II) complex 11 was obtained by an analogous reaction of $\mathrm{CoCl}_{2}$ with 2 .

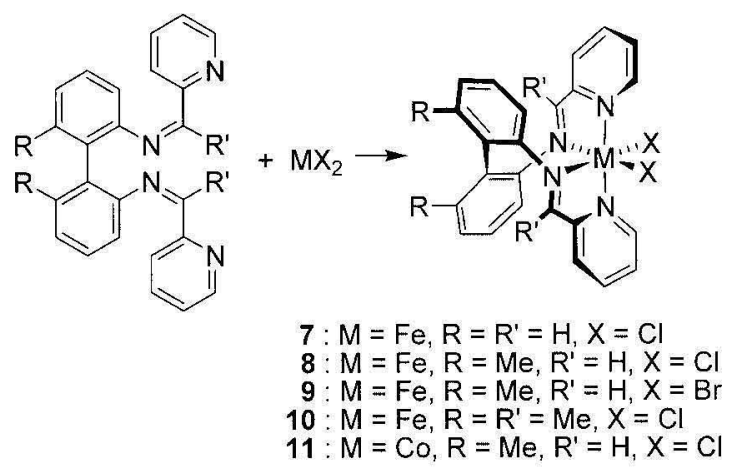

Single crystals of the dichloro complexes $\mathbf{8}$ and $\mathbf{1 1}$ were obtained by layering their dichloromethane solutions with pentane or toluene, respectively. The complexes are isostructural and crystallize in the monoclinic space group $C 2 / c$ with cell constants deviating by less than $0.2 \AA$ and less than $0.5^{\circ}$ (Figure 1, Table 1). The distorted octahedral complexes, with cis-positioned chlorine atoms, both possess crystallographic $C_{2}$-symmetry. $\mathrm{Co}-\mathrm{N}$ bonds are approximately $0.05 \AA$ shorter than their $\mathrm{Fe}-\mathrm{N}$ counterparts (Table 1), presumably a consequence of higher nuclear charge and more strongly contracted metal d-orbitals of cobalt. $\mathrm{Fe}-\mathrm{N}$ distances are within the range generally observed in neutral, octahedral iron complexes. ${ }^{[9]}$ The bond angles $\angle \mathrm{N} 1-\mathrm{M}-\mathrm{Cl} 1, \angle \mathrm{N} 2-\mathrm{M}-\mathrm{Cl} 1$ and $\angle \mathrm{N} 2-\mathrm{M}-\mathrm{Cl} 1 \mathrm{~A}$ (M $=\mathrm{Fe}, \mathrm{Co})$ at each of the metal centers deviate by less than $2^{\circ}$ from each other and from the value of $90^{\circ}$ expected for octahedral coordination. The bite angles of the twisted seven-membered chelate ring, $\angle \mathrm{N} 1-\mathrm{M}-\mathrm{N} 1 \mathrm{~A}=73-74^{\circ}$, and of the five-membered chelate rings, $\angle \mathrm{N} 1-\mathrm{M}-\mathrm{N} 2=73-74^{\circ}$, however, are both significantly smaller than $90^{\circ}$ and lead to a distortion of the octahedral coordination, i.e. to an opening of the angle $\angle \mathrm{Cl} 1-\mathrm{M}-\mathrm{Cl} 1 \mathrm{~A}$ to a value of $110-112^{\circ}$ (Table 1). Due to the twisted bianiline backbone, the planes formed by N1, N1A, and M and by M, Cl1, and C11A deviate from each other by $26-28^{\circ}$.

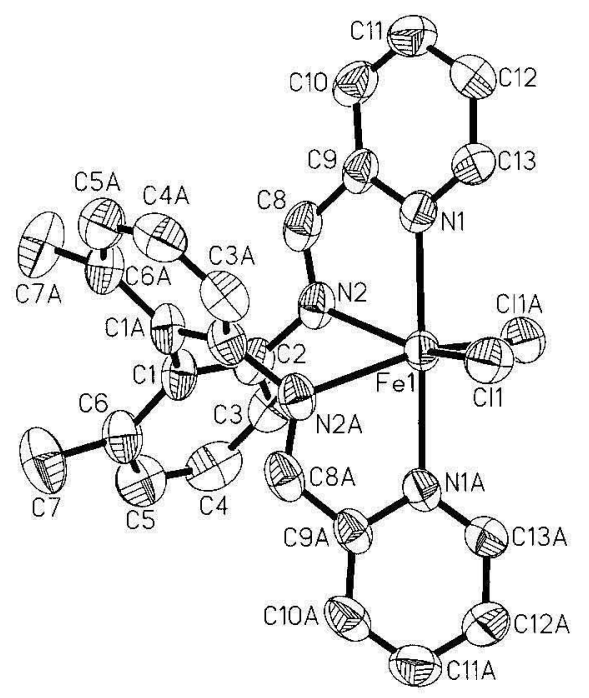

Figure 1. Crystal structures of complex $\mathbf{8}$; hydrogen atoms omitted for clarity, thermal ellipsoids drawn at the $50 \%$ probability level

Table 1. Selected bond lengths $[\AA]$ and bond angles $\left[^{\circ}\right]$ for complexes $\mathbf{8}$ and $\mathbf{1 1}$

\begin{tabular}{lrr}
\hline & \multicolumn{1}{c}{$\mathbf{8}^{[\mathrm{a}]}$} & \multicolumn{1}{c}{$\mathbf{1 1}^{[\mathrm{b}]}$} \\
\hline M-N1 (imine) & $2.296(4)$ & $2.235(2)$ \\
M-N2 (pyridine) & $2.214(3)$ & $2.175(2)$ \\
M-Cl1 & $2.397(2)$ & $2.401(1)$ \\
N1-M-N1A & $72.8(2)$ & $73.8(1)$ \\
N2-M-N2A & $178.6(2)$ & $178.8(1)$ \\
X1-M-Cl1A & $111.6(1)$ & $109.8(1)$ \\
N1-M-N2 & $72.9(1)$ & $74.0(1)$ \\
N1-M-N2A & $106.0(1)$ & $107.0(1)$ \\
N1-M-Cl1 & $91.0(1)$ & $91.1(1)$ \\
N1-M-Cl1A & $152.6(1)$ & $154.2(1)$ \\
N2-M-Cl1 & $89.4(1)$ & $88.1(1)$ \\
N2-M-Cl1A & $91.4(1)$ & $91.3(1)$ \\
\hline
\end{tabular}

[a] 8: $\mathrm{M}=\mathrm{Fe},[\mathrm{b}]$ 11: $\mathrm{M}=\mathrm{Co}$. 
For the magnetic moments of complexes 8 and 11, highspin values of $\mu_{\mathrm{eff}}=5.47 \mu_{\mathrm{B}}$ and $\mu_{\mathrm{eff}}=4.96 \mu_{\mathrm{B}}$, respectively, were measured by the SQUID method at $300 \mathrm{~K}$. No indication for any thermally induced spin-crossover between $90 \mathrm{~K}$ and $300 \mathrm{~K}$ was obtained in either case. In this regard, complex 8 falls in line with related $\mathrm{Fe}^{\mathrm{II}}$ complexes such as [bis(bipyridyl) $\mathrm{FeCl}_{2}$ ] or bis(phenanthrolin) $\mathrm{FeCl}_{2}$, for which high-spin configurations have likewise been reported. ${ }^{[10]}$

In the ${ }^{1} \mathrm{H}$ NMR spectrum of the paramagnetic iron(II) complex 8 in $\mathrm{CDCl}_{3}$ solution, nine signals are detected over a range of nearly $190 \mathrm{ppm}$ (Figure 2), in agreement with a time-averaged $C_{2}$-symmetric complex geometry. Based on the observed signal intensities, the resonance at $\delta=-6.72$ ppm is clearly identified as being due to the methyl groups. Since no signal above $\delta=120$ is displayed in the NMR spectrum of complex 10 , which contains, instead of the aldimine ligand 2 , the analogous ketimine ligand 6 , we can conclude that the resonance of complex 8 at $\delta \approx 180$ ppm must be due to its aldimine protons.

Assignments of further signals are based on their relative line widths: Up to a distance of ca. $5 \AA$ from the metal center, relative line widths of two nuclei A and B depend reciprocally on the ratio of their distances from the metal center, $v_{2}(\mathrm{~A}) / v_{2}(\mathrm{~B}) \approx\left(d_{\mathrm{B}} / d_{\mathrm{A}}\right)^{6} .{ }^{[11]}$ The remaining signals can thus be assigned as shown in Figure 2 and Table 2.

${ }^{1} \mathrm{H}$ NMR spectra of complexes 7 and $9-11$ in $\mathrm{CDCl}_{3}$ solution, which are likewise in agreement with timeaveraged $C_{2}$ symmetry, were assigned in a manner similar to that used for 8 (see Exp. Sect.). Complexes 7, 9, and 10, for which crystal structure determinations are not available, could in principle adopt the $C_{2}$-symmetric geometries indicated by their ${ }^{1} \mathrm{H}$ NMR spectra with their two chlorine ligands either in trans- or in cis-configuration. In order to ascertain, whether these complexes have the same cis-halide geometry as found for $\mathbf{8}$ and $\mathbf{1 1}$, we have characterized these complexes also by their far-infrared vibrational spectra.

For a $C_{2 v}$-symmetric complex of the type $\left[\right.$ cis- $\left.\mathrm{N}_{4} \mathrm{FeCl}_{2}\right]$, four $\mathrm{Fe}-\mathrm{N}$ and two $\mathrm{Fe}-\mathrm{Cl}$ vibrations are expected to be IRactive. For $\left[\right.$ trans- $\mathrm{N}_{4} \mathrm{FeCl}_{2}$ ] with approximate $D_{4 h}$ symmetry, however, only one $\mathrm{Fe}-\mathrm{N}$ and one $\mathrm{Fe}-\mathrm{Cl}$ vibration would be IR-active, if no distinction is made between imine and pyridine $\mathrm{N}$ atoms. ${ }^{[12]}$ In the IR spectra of solid $\mathbf{8 , 9}$, and $\mathbf{1 1}$

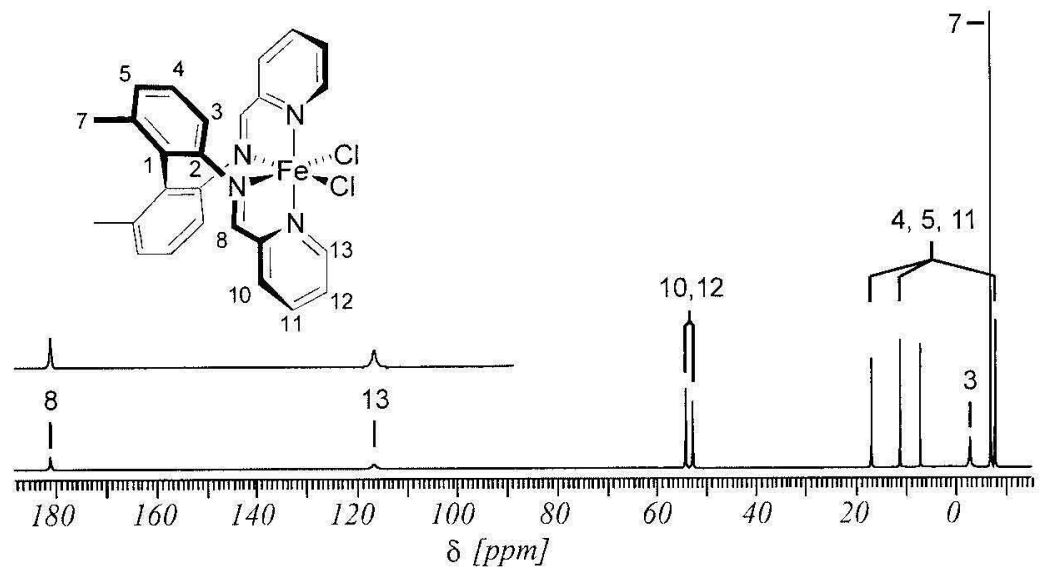

Figure 2. ${ }^{1} \mathrm{H}$ NMR spectrum of the paramagnetic complex 8 in $\mathrm{CDCl}_{3}$ solution at $25^{\circ} \mathrm{C}(600 \mathrm{MHz}$; numbering as in the crystal structure represented in Figure 1)

Table 2. Assignment of ${ }^{1} \mathrm{H}$ NMR resonances of complex $\mathbf{8}^{[\mathrm{a}]}$

\begin{tabular}{|c|c|c|c|c|c|}
\hline & $\begin{array}{c}d(\mathrm{H}- \\
\mathrm{Fe}) / \AA^{[b]}\end{array}$ & $d^{6} \cdot 10^{5} \cdot \AA^{6}$ & $\gamma_{1 / 2, \text { calcd } d} / H^{[c]}$ & $v_{/ 2, \exp } / \mathrm{Hz}$ & $\delta / \mathrm{ppm}^{[\mathrm{d}]}$ \\
\hline $13-\mathrm{H}$ & 3.250 & 84,86 & 703 & 520 & 116.2 \\
\hline $3-\mathrm{H}$ & 3.977 & 25.27 & 210 & 149 & -2.6 \\
\hline $8-\mathrm{H}$ & 4.110 & 20.75 & 172 & $172^{[\mathrm{e}]}$ & 180.7 \\
\hline $10-\mathrm{H}$ & 5.218 & 4.95 & 41 & \multirow{2}{*}{$66 / 57$} & \multirow{2}{*}{$52.8 / 54.20$} \\
\hline $12-\mathrm{H}$ & 5.311 & 4.46 & 37 & & \\
\hline $4-\mathrm{H}$ & 5.918 & 2.33 & 19 & \multirow{3}{*}{$42 / 36 / 30$} & \multirow{3}{*}{$17.1 / 11.4 /-7.6$} \\
\hline $11-\mathrm{H}$ & 6.074 & 1.99 & 17 & & \\
\hline $5-\mathrm{H}$ & 6.678 & 1.13 & 9 & & \\
\hline 7- $\mathrm{CH}_{3}$ & 6.665 & 1.14 & 9 & $29^{[e]}$ & -6.7 \\
\hline
\end{tabular}

[a] Numbering corresponding to that used for the crystal structure in Figure 1. [b] Taken from the crystal structure of 8 . [c] Calculated relative to $8-\mathrm{H}$. [d] For temperature dependence of these paramagnetic shift values see Supporting Information. [e] Assigned independently (see text). 
(Table 3) four medium to strong vibrations are observed between ca. 180 and $350 \mathrm{~cm}^{-1} \cdot{ }^{[13]}$ We assign these bands, which are absent in the IR spectrum of the free ligand 2, to metal- $\mathrm{N}$ vibrations.

Table 3. Far-infrared absorption bands of ligand 2 and of complexes $\mathbf{8}, \mathbf{9}$, and 11 (positions in $\mathrm{cm}^{-1}$ )

\begin{tabular}{|c|c|c|c|c|}
\hline 2 & 8 & 9 & 11 & Assignment \\
\hline $590(\mathrm{~s})$ & $590(w)$ & $588(\mathrm{~m})$ & 591 (m) & ligand \\
\hline $549(\mathrm{~m})$ & $555(\mathrm{~m})$ & $557(\mathrm{~s})$ & $558(\mathrm{~m})$ & ligand \\
\hline \multirow[t]{2}{*}{$520(\mathrm{~m})$} & $536(w)$ & $535(w)$ & $496(\mathrm{~m})$ & ligand \\
\hline & $515(\mathrm{~m})$ & $\begin{array}{l}522(\mathrm{w}) \\
512(\mathrm{w})\end{array}$ & & \\
\hline $475(\mathrm{~s})$ & $474(\mathrm{~m})$ & $479(\mathrm{~s})$ & $484(\mathrm{~s})$ & ligand \\
\hline $440(w)$ & $437(w)$ & $423(w)$ & $430(\mathrm{~m})$ & ligand \\
\hline $404(\mathrm{~s})$ & $416(\mathrm{~s})$ & $414(\mathrm{~m})$ & & ligand \\
\hline \multirow[t]{2}{*}{$368(\mathrm{~m})$} & $386(w)$ & $371(w)$ & $379(w)$ & ligand \\
\hline & $337(\mathrm{~m})$ & $339(\mathrm{~m})$ & $341(\mathrm{~m})$ & $\mathrm{M}-\mathrm{N}$ \\
\hline \multirow[t]{2}{*}{$316(\mathrm{~m})$} & & $318(w)$ & & ligand \\
\hline & $300(\mathrm{~s})$ & $297(\mathrm{~s})$ & $308(\mathrm{~s})$ & $\mathrm{M}-\mathrm{N}$ \\
\hline $260(\mathrm{~m})$ & $271(w)$ & $269(\mathrm{~m})$ & $270(\mathrm{~m})$ & ligand \\
\hline \multirow[t]{6}{*}{$240(\mathrm{~m})$} & 244 (vs) & $241(\mathrm{~m})$ & $242(\mathrm{~s})$ & $\begin{array}{l}\text { ligand, } \\
\mathrm{M}-\mathrm{Cl} \text { in } 8 \text { and } \\
\mathbf{1 1}\end{array}$ \\
\hline & c. f. [13] & $223(\mathrm{~s})$ & $225(\mathrm{~m})$ & $\mathrm{M}-\mathrm{N}$ \\
\hline & $192(\mathrm{~m})$ & $191(\mathrm{~s})$ & $181(\mathrm{~m})$ & $\mathrm{M}-\mathrm{N}$ \\
\hline & & $174(s)$ & & $\mathrm{Fe}-\mathrm{Br}$ \\
\hline & $144(\mathrm{~s})$ & & $135(\mathrm{~s})$ & $\mathrm{M}-\mathrm{Cl}$ \\
\hline & & $104(\mathrm{~s})$ & & $\mathrm{Fe}-\mathrm{Br}$ \\
\hline
\end{tabular}

Two further strong peaks are observed at 244 and $144 \mathrm{~cm}^{-1}$ for complex 8 and at 174 and $104 \mathrm{~cm}^{-1}$ for its dibromo homologue 9. The 1.4:1 ratio of these wavenumbers, which is close to the theoretical value of 1.5 estimated from the ratio of reduced masses of $\mathrm{Fe}-\mathrm{Cl}$ and $\mathrm{Fe}-\mathrm{Br}$, supports the assignment of these bands to the symmetric and asymmetric stretching modes of a cis-FeX $\mathrm{X}_{2}$ unit. The $\mathrm{Co}-\mathrm{Cl}$ vibrations of 11 were found at 242 and $135 \mathrm{~cm}^{-1}$, as expected only slightly below those of $\mathbf{8}$. Analogous assignments hold for $\mathbf{7}$ and 10. Complexes 7-11 thus all contain cis-coordinated halogen ligands in the solid state.

While the chiral, $C_{2}$-symmetric complexes 7-11 have the cis-positioned homotopic sites required for enantioselective olefin insertion, substituents bigger than hydrogen would be desirable in the 6-positions of the pyridine rings, so as to transfer the axial chirality of the biphenyl backbone most effectively to the coordination sites of the complex (Figure 3).

In order to obtain a homologue of complex 8 with methyl substituents in both pyridyl 6-positions, $\mathrm{FeCl}_{2}$ was reacted with ligand $\mathbf{3}$. Reactions in THF yielded $\mathbf{1 2} \cdot$ THF as a brown solid. The same product, without THF, was obtained from reactions in $\mathrm{CH}_{2} \mathrm{Cl}_{2}$. In contrast to complexes 7-11, complex 12 gives a ${ }^{1} \mathrm{H}$ NMR spectrum with only three broad signals centered at $\delta=3.45,-4.91$, and -11.39 . Only two strong and one medium vibration at 367,319 , and $268 \mathrm{~cm}^{-1}$, respectively, are apparent in its far-infrared spectrum, again in contrast to complexes 7-11, where four $\mathrm{M}-\mathrm{N}$ and two $\mathrm{M}-\mathrm{X}$ vibrations have been observed. The $C_{2}$-symmetric geometry found for these complexes is thus unlikely to be adopted by complex 12 .
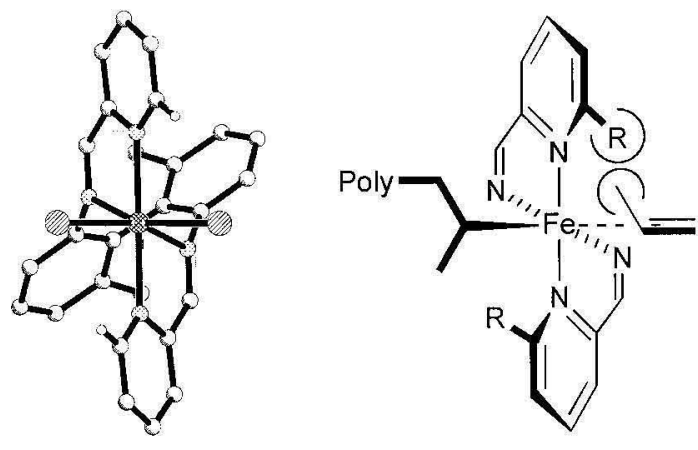

Figure 3. Front view of complex 8 (left) and of a putative Fe-polymeryl $\pi$ complex (right) with propene coordinated by its disfavored enantioface (biphenyl bridge omitted for clarity)

The only useful structural clue is derived from SQUID measurements, which yielded for complex 12 an effective magnetic moment of $\mu_{\mathrm{eff}}=3.41 \mu_{\mathrm{B}}$, indicative of 2-3 unpaired electrons, i.e. of a configuration with partly paired electron spins. The ligand field separation $\Delta E=10 D q$ of the octahedral complexes $\mathbf{7 - 1 1}$ is clearly insufficient to induce any spin pairing, and the same holds, a fortiori, for tetrahedral or trigonal bipyramidal geometries (Figure 4). The only plausible coordination geometry, which would be in agreement with the partial spin pairing observed for $\mathbf{1 2}$, is that of a square pyramidal complex, e. g. of a species [(3) $\mathrm{FeCl}]^{+} \mathrm{Cl}^{-}$, in which one of the chloride ligands has been eliminated from the metal center due to steric repulsions by the methyl-substituted pyridyl ligands. To reach a square pyramidal geometry, at least three of the four $\mathrm{N}$ ligand atoms must be positioned in the square base plane of the complex (Scheme 2). Rearrangements between alternative connectivities, which are likely to occur quite rapidly, as well as chloride dissociation and re-association equilibria would plausibly explain the observed broadening of the NMR signals of $\mathbf{1 2}{ }^{[14]}$

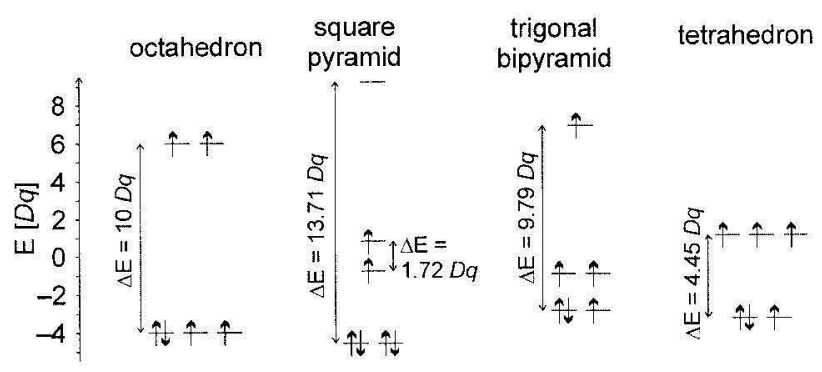

Figure 4. Effects of different complex geometries with moderately strong ligand field on $\mathrm{d}^{6}$ electron configurations (values taken from ref. ${ }^{[15]}$ )

In order to obtain also bona-fide low-spin complexes with the bianiline-bridged ligand framework under consideration, complex $\mathbf{8}$ was reacted with methylmagnesium chloride [Equation (3)]. The diamagnetic dimethyl complex 13 was obtained from this reaction as a brown powder. ${ }^{[16]}$ Its ${ }^{1} \mathrm{H}$ NMR spectrum revealed a $C_{1}$-symmetric geometry in solution. The same geometry was also found for its counterpart with isocyanide instead of methyl ligands. This sec- 


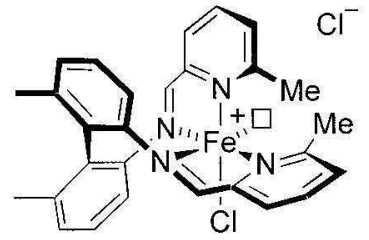

12

Scheme 2. Structure proposed for complex $\mathbf{1 2}$

ond low-spin derivative, the orange-red complex 14 was obtained by reaction of complex $\mathbf{8}$ with two equivalents each of AgOTf and tert-butyl isocyanide [Equation (3)]. ${ }^{[17]}$ The ${ }^{1} \mathrm{H}$ NMR spectrum of $\mathbf{1 4}$ (see Exp. Sect.) confirmed the coordination of two isocyanide ligands, and indicated, again, a $C_{1}$-symmetric geometry.

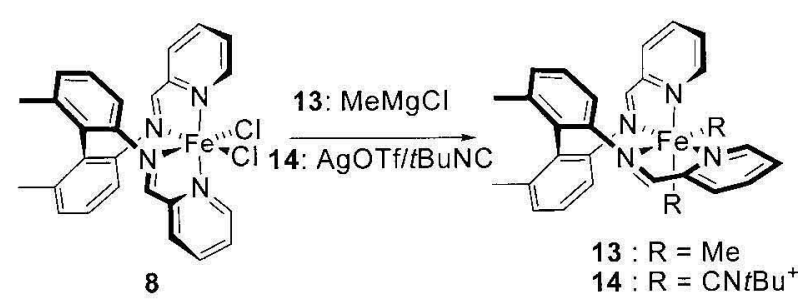

This structural assignment is supported by the results of an X-ray diffraction study (Figure 5, Table 4): In the cationic diisocyanide complex 14 , three of the four $\mathrm{N}$ ligand atoms reside in one meridional plane; in the second meridional plane, one of the pyridyl moieties and the two tertbutyl isocyanide ligands are coordinated to the iron center. ${ }^{[18]}$

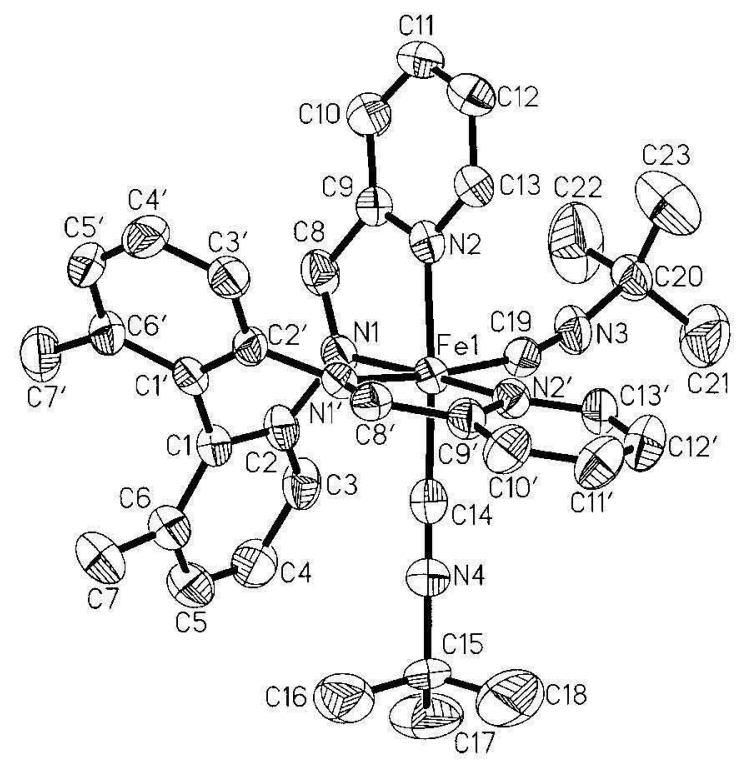

Figure 5. Crystal structure of the complex cation 14; hydrogen atoms, triflate anions and co-crystallized solvent omitted for clarity, thermal ellipsoids drawn at the $50 \%$ probability level

The overall $C_{1}$ symmetry of this complex appears to be stabilized by one or more of the following factors: Close
Table 4 . Selected bond lengths $[\AA]$ and angles $\left[{ }^{\circ}\right]$ for complex 14

\begin{tabular}{lclr}
\hline $\mathrm{Fe}-\mathrm{N} 1$ (imine) & $1.940(5)$ & $\mathrm{N} 1^{\prime}-\mathrm{Fe}-\mathrm{N} 2$ & $89.7(2)$ \\
$\mathrm{Fe}-\mathrm{N} 1^{\prime}$ (imine) ${ }^{[\mathrm{a}]}$ & $2.001(4)$ & $\mathrm{N} 1^{\prime}-\mathrm{Fe}-\mathrm{N} 2^{\prime}$ & $81.5(2)$ \\
$\mathrm{Fe}-\mathrm{N} 2$ (pyridine) & $2.014(4)$ & $\mathrm{N} 1^{\prime}-\mathrm{Fe} \mathrm{C} 14$ & $90.1(2)$ \\
$\mathrm{Fe}-\mathrm{N} 2^{\prime}$ (pyridine) & $2.002(5)$ & $\mathrm{N} 1^{\prime}-\mathrm{Fe}-\mathrm{C} 19$ & $172.8(2)$ \\
[a] & & & \\
$\mathrm{Fe}-\mathrm{C} 14$ & $1.904(6)$ & $\mathrm{N} 2-\mathrm{Fe}-\mathrm{N} 2^{\prime}$ & $99.8(2)$ \\
$\mathrm{Fe}-\mathrm{C} 19$ & $1.884(6)$ & $\mathrm{N} 2-\mathrm{Fe}-\mathrm{Cl} 14$ & $176.0(2)$ \\
& & $\mathrm{N} 2-\mathrm{Fe}-\mathrm{C} 19$ & $84.1(2)$ \\
$\mathrm{N} 1-\mathrm{Fe}-\mathrm{N} 1 \mathrm{~A}$ & $90.0(2)$ & $\mathrm{N} 2^{\prime}-\mathrm{Fe}-\mathrm{C} 14$ & $84.1(2)$ \\
$\mathrm{N} 1-\mathrm{Fe}-\mathrm{N} 2$ & $80.4(2)$ & $\mathrm{N} 2^{\prime}-\mathrm{Fe}-\mathrm{C} 19$ & $96.0(2)$ \\
$\mathrm{N} 1-\mathrm{Fe}-\mathrm{N} 2 \mathrm{~A}$ & $171.4(2)$ & $\mathrm{C} 14-\mathrm{Fe} \mathrm{C} 19$ & $96.4(2)$ \\
$\mathrm{N} 1-\mathrm{Fe}-\mathrm{C} 14$ & $95.7(2)$ & $\mathrm{C} 14-\mathrm{N} 4-\mathrm{C} 15$ & $175.4(7)$ \\
$\mathrm{N} 1-\mathrm{Fe}-\mathrm{C} 19$ & $92.5(2)$ & $\mathrm{C} 19-\mathrm{N} 3-\mathrm{C} 20$ & $167.8(5)$
\end{tabular}

adherence to idealized octahedral geometry and a shortening of the $\mathrm{Fe}-\mathrm{N}$ bonds, which is presumably required by the low-spin configuration of $\mathbf{1 4}$, is more easily adopted by a $C_{1}$ - than by a $C_{2}$-symmetric geometry, as indicated by the ligand - metal-ligand bite angles in 14 (Table 4), which are much closer to $90^{\circ}$ than those of the $C_{2}$-symmetric complex 8 (Table 1). In addition, the pyridyl ligands are likely to prefer a cis over a trans arrangement in order to utilize different $\mathrm{d}$ orbitals for backdonation. A possible preference of isocyanide ligands to coordinate trans to pyridine, finally, can be satisfied, for at least one of the isocyanide ligands, only in the $C_{1}$-symmetric geometry shown in Figure $5 .{ }^{[19]}$

\section{Polymerization Experiments}

Reaction conditions suitable for catalytic polymerization of ethene were sought in particular using complex $\mathbf{8}$ as precatalyst. When very finely dispersed suspensions of 10 $20 \mathrm{mg}$ (ca. $20-40 \mu \mathrm{mol}$ ) of turquoise 8 in $120 \mathrm{~mL}$ of toluene, prepared by extended exposure to an ultrasound bath, were reacted with a toluene solution of methylalumoxane (MAO) in a glass-walled reactor, with $[\mathrm{Al}] /[\mathrm{Fe}]$ ratios varying between 30:1 and 1000:1, dark green solutions were obtained. Exposure of such a solution to 2-4 bar of ethene or propene yielded only miniscule flakes of polymer (if any), which escaped any isolation attempts. Neither particularly careful exclusion of air and moisture from the reaction mixture nor its deliberate exposure to the atmosphere or even addition of oxidizing reagents, such as $[\mathrm{NO}]\left[\mathrm{BF}_{4}\right]$ or Meerwein salt, which are capable of oxidizing $\mathrm{Fe}^{\mathrm{II}}$ complexes, ${ }^{[20]}$ gave any more positive results, nor was this the case when the $\mathrm{Fe}^{\mathrm{III}}$ complex $[8]^{+} \mathrm{Cl}^{-}$was separately synthesized (see Exp. Sect.) and tested with regard to its catalytic activity after reaction with MAO or with trityl perfluorotetraphenyl borate and $(i \mathrm{Bu})_{3} \mathrm{Al}{ }^{[21]}$

Remarkably, however, significant amounts of polymer were obtained, when $20-50 \mathrm{mg}$ (ca. $40-100 \mu \mathrm{mol}$ ) of solid complex 8 in toluene were activated, without being finely dispersed by ultrasound treatment, by addition of a toluene solution of $\mathrm{MAO}$, at $[\mathrm{Al}] /[\mathrm{Fe}]$ ratios of ca. 55-85:1. When the black viscous tar, obtained from this activating procedure, was introduced into a stainless-steel reactor and then immediately exposed to 30 bar of ethene at reaction temperatures of $0-40^{\circ} \mathrm{C}$, yields of $40-160 \mathrm{mg}$ polyethene 
were reproducibly isolated after a reaction time of 4 hours, ${ }^{[22]}$ corresponding to productivities of ca. $160-1000 \mathrm{~g}$ polymer/(mol $\mathrm{Fe} \cong \mathrm{h})$ (Table 5 ). In analogous experiments with complexes 10 and 12, no polymer was obtained although these experiments followed a protocol which had proven successful for complex $\mathbf{8}$.

Table 5.Conditions and results of olefin polymerization reactions ${ }^{[a]}$

\begin{tabular}{lcccccc}
\hline Run & $\begin{array}{c}\text { Catalyst } \\
{[\mu \mathrm{mol}]}\end{array}$ & $\begin{array}{c}\mathrm{MAO} \\
{[\mathrm{Al}]:[\mathrm{Fe}]}\end{array}$ & $\begin{array}{c}T_{\mathrm{p}} \\
{\left[{ }^{\circ} \mathrm{C}\right]}\end{array}$ & $\begin{array}{c}\text { Monomer } \\
{[\text { bar }]}\end{array}$ & $\begin{array}{c}\text { Ultra- } \\
\text { sound } \\
\text { treatment }\end{array}$ & $\begin{array}{c}\text { Poly- } \\
\text { mer } \\
\text { yield }\end{array}$ \\
\hline 1 & $\mathbf{8 , 3 8 . 7}$ & $30: 1$ & 20 & ethene, 4 & yes & traces \\
2 & $\mathbf{8}, 29.8$ & $100: 1$ & 30 & ethene, 2 & yes & $60 \mathrm{mg}$ \\
3 & $\mathbf{8}, 27.5$ & $300: 1$ & 40 & ethene, 4 & yes & traces \\
4 & $\mathbf{8}, 18.4$ & $1000: 1$ & 40 & ethene, 2 & yes & traces \\
5 & $\mathbf{8 , 3 4 . 0}$ & $70: 1$ & 30 & propene, 2 & yes & 0 \\
6 & $\mathbf{8 , 2 6 . 3}$ & T-FPB ${ }^{[\mathrm{b}]}$ & 30 & propene, 2 & yes & 0 \\
7 & $\mathbf{8}, 94.7$ & $100: 1$ & 25 & ethene, 30 & yes & traces \\
8 & $\mathbf{8 , 7 3 . 5}$ & $70: 1$ & 40 & ethene, 30 & yes & 0 \\
9 & $\mathbf{8 , 4 0 . 8}$ & $85: 1$ & 25 & ethene, 30 & no & $160 \mathrm{mg}$ \\
10 & $\mathbf{8 , 6 9 . 4}$ & $73: 1$ & 10 & ethene, 30 & no & $60 \mathrm{mg}$ \\
11 & $\mathbf{8 , 4 7 . 4}$ & $55: 1$ & 0 & ethene, 30 & no & $100 \mathrm{mg}$ \\
12 & $\mathbf{1 0}, 50.1$ & $100: 1$ & 25 & ethene, 30 & no & 0 \\
13 & $\mathbf{1 2 , 4 2 . 2}$ & $120: 1$ & 25 & ethene, 30 & no & 0 \\
\hline
\end{tabular}

[a] Reaction conditions: $120 \mathrm{~mL}$ of toluene; reaction time, 4 hours; 1-5 min. pre-incubation with cocatalyst. [b] Trityl (perfluorotetraphenyl)borate (1 equiv.) and triisobutylaluminum $(0.5 \mathrm{~mL})$.

\section{Conclusions}

The results described above indicate that complex 8 undergoes some transformation upon exposure to MAO; this does not lead to an active species, capable of inducing catalytic olefin polymerization, however, when the reaction is conducted in homogeneous solution. While no direct clues indicate the nature of the green species formed under these conditions, we can surmise, in analogy to results obtained with related reaction systems, ${ }^{[23]}$ that metal alkyl cations of the type $\mathrm{N}_{4} \mathrm{FeMe}^{+}$, most likely stabilized by uptake of a $\mathrm{MAO}$-derived $\mathrm{AlMe}_{3}$ unit, dominate in these solutions and would thus be responsible for the strongly red-shifted UV/ Vis absorption of these reaction systems. If indeed present in these solutions, these species are obviously not capable of inducing chain growth by olefin insertion. Their 16-valence electron configuration is apparently not sufficiently electron-deficient to coordinate and insert an olefin substrate, in distinction to related 14-electron cations of the type $\mathrm{N}_{3} \mathrm{FeMe}^{+}$, which are considered to be catalytically active in $\mathrm{MAO}$-activated $\mathrm{Fe}^{\mathrm{II}}$ pyridyldiimine systems. ${ }^{[23]}$

The reaction of MAO with solid particles of complex $\mathbf{8}$, on the other hand, seems to favour some other reaction paths, most likely some intermolecular ligand exchange reaction. Formation of the viscous, tarry product is likely to arise from a transfer of some of the $\mathrm{N}$ ligand atoms, e. g. of a pyridyl moiety, from one complex molecule to another, such that the resulting oligomeric or polymeric complex species now contains metal centers, which are coordinated to less than four $\mathrm{N}$ ligand atoms. More likely than not, such a reaction would lead to a collection of different coordination patterns each with its own catalytic property, rather than to a unique complex geometry.

In accord with this assumption, a gel-permeation chromatography (GPC) analysis of the polyethene samples obtained from runs $10-12$ reveals in all cases a molecular mass distribution with three distinct fractions (see Supporting Information) with $M_{n}$ values of $130-180\left(M_{\mathrm{w}} / M_{n} \approx\right.$ $1.25)$, ca. $3600-7000\left(M_{\mathrm{w}} / M_{n} \approx 1.7\right)$ and ca. $160000-320000$ $\left(M_{\mathrm{w}} / M_{n} \approx 6.2-7.1\right)$, respectively. Clearly, several catalytic species contribute to chain growth in these reaction systems. The component with highest $\mathbf{M}_{n}$ is remarkably similar, in its mean chain length as well as in its rather broad molar mass distribution, to polyethene samples obtained with typical MAO-activated iron pyridyldiimine complexes, ${ }^{[1 \mathrm{c}, 2 \mathrm{~d}]}$ in agreement with the assumption that some related catalyst species with reduced coordination number might be generated from complex 8 by the heterogeneous activation procedure described above. The observations presented here, in particular the lack of reactivity of any of our reaction systems vis-à-vis propene, ${ }^{[21]}$ let the probability of observing catalytic-site-controlled, stereoselective olefin polymerization by precatalyst structures of the type investigated in this report, appear rather remote.

\section{Experimental Section}

All preparations were performed under an argon atmosphere using standard Schlenk techniques. Solvents were dried prior to use by refluxing over and distillation from sodium (THF, hydrocarbons) or calcium hydride (dichloromethane). Deuterated solvents were dried over 4- $\AA$ molecular sieves. All other chemicals were commercially obtained and used without further purification. Melting points were determined with a Sanyo-Gallenkamp MFB-600-010F thermometer, magnetic susceptibilities with a Quantum Design Superconducting Quantum Interference Device (SQUID) MPMSXL5. NMR spectra were collected on Bruker AC 250 FT NMR or Bruker Avance DRX 600 spectrometers, IR spectra measured with a Perkin-Elmer 2000 FT-IR spectrometer, either as KBr or polyethene (PE) pellets, UV spectra of $1.0 \mathrm{mM}$ solutions in a $1-\mathrm{cm} \mathrm{cu-}$ vette with a Varian-Cary 50 and mass spectra with Finnigan MAT 312 (EI) or Finnigan AMD MAT 312/AMD 5000 (FAB) mass spectrometers. Elemental compositions were analyzed with an Elementar Vario EL device. Ligands $\mathbf{2}$ and $\mathbf{3}$ were prepared as described earlier. ${ }^{[24]}$

$N, N^{\prime}$-(Biphenyl-2,2'-diyl)bis(2-pyridylmethyl)diimine (1): A solution of $4(361 \mathrm{mg}, 1.96 \mathrm{mmol})$ in ethanol $(10 \mathrm{~mL})$ was stirred for $1 \mathrm{~h}$ with pyridine-2-carbaldehyde ( $373 \mu \mathrm{L}, 420 \mathrm{mg}, 3.92 \mathrm{mmol})$. After evaporation of solvent, 1 was obtained as a solid residue in almost quantitative yield. ${ }^{1} \mathrm{H}$ NMR $\left(250 \mathrm{MHz}, \mathrm{CDCl}_{3}, \mathrm{ppm}\right): \delta=7.11[\mathrm{~d}$, $\left.{ }^{3} J(\mathrm{H}-\mathrm{H})=7.9 \mathrm{~Hz}, 2 \mathrm{H} ; \mathrm{Ar}-\mathrm{H}\right], 7.23-7.48(\mathrm{~m}, 8 \mathrm{H}, \mathrm{Ar}-\mathrm{H}), 7.66[\mathrm{t}$, ${ }^{3} J(\mathrm{H}-\mathrm{H})=7.3 \mathrm{~Hz}, 2 \mathrm{H}$; Ar-H], $7.79\left[\mathrm{~d},{ }^{3} J(\mathrm{H}-\mathrm{H})=7.9 \mathrm{~Hz}, 2 \mathrm{H}\right.$; $\mathrm{Ar}-\mathrm{H}], 8.34$ (s, $2 \mathrm{H}, \mathrm{N}=\mathrm{CH}), 8.49\left[\mathrm{~d},{ }^{3} J(\mathrm{H}-\mathrm{H})=4.3 \mathrm{~Hz}, 2 \mathrm{H} ; 6^{\prime \prime}-\right.$ $\mathrm{H}]$. Since 1 was not obtainable in powdered form, the solid residue was dissolved in THF and used for further reactions.

$N, N^{\prime}-\left(6,6^{\prime}\right.$-Dimethylbiphenyl-2,2'-diyl)bis[1-(2-pyridyl)ethyldiimine (6): To a solution of $5(4.45 \mathrm{~g}, 21.0 \mathrm{mmol})$ in toluene $(100 \mathrm{~mL})$ was added 2-acetylpyridine $(4.70 \mathrm{~mL}, 5.08 \mathrm{~g}, 41.9 \mathrm{mmol})$ and para-toluenesulfonic acid hydrate $(797 \mathrm{mg}, 4.19 \mathrm{mmol})$. After refluxing the reaction mixture in a Dean-Stark aparatus for 3 days, the solvent 
was evaporated. The residue was suspended in $200 \mathrm{~mL}$ of diethyl ether, freed from solids by filtration and the solids washed with diethyl ether. The combined ether fractions were extracted with diluted sodium hydroxide solution $(200 \mathrm{~mL})$ and subsequently dried with $\mathrm{MgSO}_{4}$. After evaporation of solvent, a brown crude product was obtained $(6.97 \mathrm{~g})$, which contained, according to its ${ }^{1} \mathrm{H} \mathrm{NMR}$, $24 \%$ toluene, $6 \% 5,12 \% 2$-acetylpyridine, $21 \%$ of the mono condensation product, and $37 \%$ of 6 . Attempted purification by column chromatography on silica gel lead to decomposition of 6 to the starting materials. Since this crude ligand was suitable for complex formation, no further attempts were undertaken to purify it. Yield (calculated on ${ }^{1} \mathrm{H}$ NMR basis) $2.58 \mathrm{~g}(6.16 \mathrm{mmol}, 29 \%) .{ }^{1} \mathrm{H}$ NMR $\left(250 \mathrm{MHz}, \mathrm{CDCl}_{3}, \mathrm{ppm}\right): \delta=2.14\left(\mathrm{~s}, 6 \mathrm{H}, 6-\mathrm{CH}_{3} / 6^{\prime}-\mathrm{CH}_{3}\right), 2.28(\mathrm{~s}$, $\left.6 \mathrm{H}, \mathrm{N}=\mathrm{C}-\mathrm{CH}_{3}\right), 6.57\left[\mathrm{~d},{ }^{3} J(\mathrm{H}-\mathrm{H})=7.9 \mathrm{~Hz}, 2 \mathrm{H} ; 3-\mathrm{H} / 3-\mathrm{H}\right], 7.03$ $\left[\mathrm{d},{ }^{3} \mathrm{~J}(\mathrm{H}-\mathrm{H})=7.3 \mathrm{~Hz}, 2 \mathrm{H}\right.$; 5-H/5'-H], 7.15-7.30 (m, $4 \mathrm{H}, 4-\mathrm{H} / 4^{\prime}-$ $\left.\mathrm{H}, 5^{\prime \prime}-\mathrm{H}\right), 7.56-7.67\left(\mathrm{~m}, 4 \mathrm{H}, 3^{\prime \prime}-\mathrm{H}, 4^{\prime \prime}-\mathrm{H}\right), 8.55\left[\mathrm{~d},{ }^{3} J(\mathrm{H}-\mathrm{H})=\right.$ $\left.4.9 \mathrm{~Hz}, 2 \mathrm{H} ; 6^{\prime \prime}-\mathrm{H}\right]$.

General Procedure for the Synthesis of Dihalogeno Metal(II) Complexes 7-11: To a stirred suspension of the metal halide in THF $(10 \mathrm{~mL} / \mathrm{mmol})$, a solution of 1.02 equiv. of the ligand in THF $(10 \mathrm{~mL} / \mathrm{mmol})$ was slowly added. After stirring overnight, the solvent was evaporated and the residue extracted four times with $\mathrm{CH}_{2} \mathrm{Cl}_{2}(4 \times 20 \mathrm{~mL} / \mathrm{mmol})$. The combined extracts were evaporated to dryness and the remaining solids suspended in diethyl ether $(15 \mathrm{~mL} / \mathrm{mmol})$. The complex was collected by filtration, washed with diethyl ether $(3 \times 5 \mathrm{~mL} / \mathrm{mmol})$, once with pentane $(5 \mathrm{~mL} /$ $\mathrm{mmol}$ ), and finally dried in vacuo.

Dichloro[ $N, N^{\prime}$-(biphenyl-2,2'-diyl)bis(2-pyridylmethyl)diimine]iron(II) $\cdot 0.5 \mathrm{CH}_{2} \mathrm{Cl}_{2}\left(7 \cdot 0.5 \mathrm{CH}_{2} \mathrm{Cl}_{2}\right)$ : A solution of 1 , obtained from 4 $(361 \mathrm{mg}, 1.96 \mathrm{mmol})$ and pyridine-2-carbaldehyde $(373 \mu \mathrm{L}, 420 \mathrm{mg}$, $3.92 \mathrm{mmol})$, in THF $(20 \mathrm{~mL})$ was reacted, following the general procedure, with $\mathrm{FeCl}_{2}(246 \mathrm{mg}, 1.94 \mathrm{mmol})$ to yield blue $7 \cdot 0.5 \mathrm{CH}_{2} \mathrm{Cl}_{2}(858 \mathrm{mg}, 1.61 \mathrm{mmol}, 83 \%)$. ${ }^{1} \mathrm{H}$ NMR $(600 \mathrm{MHz}$, $\left.\mathrm{CDCl}_{3}, \mathrm{ppm}\right): \delta=-8.29\left(\mathrm{~s}, \Delta v_{1 / 2}=72.3 \mathrm{~Hz}, 2 \mathrm{H} ; 4-\mathrm{H} / 4^{\prime}-\mathrm{H}\right.$ or $5-\mathrm{H} /$ $5^{\prime}-\mathrm{H}$ or $\left.4^{\prime \prime}-\mathrm{H}\right),-4.20$ (s, $\left.\Delta v_{1 / 2}=179 \mathrm{~Hz}, 2 \mathrm{H} ; 3-\mathrm{H} / 3^{\prime}-\mathrm{H}\right), 5.34(\mathrm{~s}$, $\left.\Delta v_{1 / 2}=61.5 \mathrm{~Hz}, 1 \mathrm{H} ; \mathrm{CH}_{2} \mathrm{Cl}_{2}\right), 6.42\left(\mathrm{~s}, \Delta v_{1 / 2}=78.8 \mathrm{~Hz}, 2 \mathrm{H} ; 6-\mathrm{H} /\right.$ $\left.6^{\prime}-\mathrm{H}\right), 11.07\left(\mathrm{~s}, \Delta v_{1 / 2}=76.9 \mathrm{~Hz}, 2 \mathrm{H} ; 4-\mathrm{H} / 4^{\prime}-\mathrm{H}\right.$ or $5-\mathrm{H} / 5^{\prime}-\mathrm{H}$ or $4^{\prime \prime}-$ $\mathrm{H}), 17.61\left(\mathrm{~s}, \Delta v_{1 / 2}=94.9 \mathrm{~Hz}, 2 \mathrm{H} ; 4-\mathrm{H} / 4^{\prime}-\mathrm{H}\right.$ or $5-\mathrm{H} / 5^{\prime}-\mathrm{H}$ or $4^{\prime \prime}{ }^{\prime}$ $\mathrm{H}), 55.12\left(\mathrm{~s}, \Delta v_{1 / 2}=119 \mathrm{~Hz}, 2 \mathrm{H} ; 3^{\prime \prime}-\mathrm{H}\right.$ or $\left.5^{\prime \prime}-\mathrm{H}\right), 56.01\left(\mathrm{~s}, \Delta v_{1 / 2}\right.$ $=113 \mathrm{~Hz}, 2 \mathrm{H} ; 3^{\prime \prime}-\mathrm{H}$ or $\left.5^{\prime \prime}-\mathrm{H}\right), 116.53\left(\mathrm{~s}, \Delta v_{1 / 2}=575 \mathrm{~Hz} ; 2 \mathrm{H}\right)$, $180.40\left(\mathrm{~s}, \Delta v_{1 / 2}=230 \mathrm{~Hz}, 2 \mathrm{H} ; \mathrm{N}=\mathrm{CH}\right) .{ }^{13} \mathrm{C} \mathrm{NMR}(151 \mathrm{MHz}$, $\left.\mathrm{CDCl}_{3}, \mathrm{ppm}\right): \delta=14.59,71.37\left(\mathrm{C}-6 / \mathrm{C}-6^{\prime}\right), 160.91\left(\mathrm{C}-4 / \mathrm{C}^{\prime} 4^{\prime}\right.$ or $\mathrm{C}-$ $5 / \mathrm{C}-5^{\prime}$ or $\left.\mathrm{C}-4^{\prime \prime}\right), 193.84,193.95,198.96,218.13\left(\mathrm{C}-4 / \mathrm{C}-4^{\prime}\right.$ or $\mathrm{C}-5 /$ $\mathrm{C}-5^{\prime}$ or $\left.\mathrm{C}-4^{\prime \prime}\right), 244.74,421.96\left(\mathrm{C}-3^{\prime \prime}\right.$ or $\left.\mathrm{C}-5^{\prime \prime}\right), 544.79$ (C-3" or C$\left.5^{\prime \prime}\right)$, other expected ${ }^{13} \mathrm{C}$ signals were not observable due to the low solubility and the low intensity of the broad ${ }^{13} \mathrm{C}$ signals. IR $(\mathrm{KBr}$, $\left.\mathrm{cm}^{-1}\right): \tilde{v}=3054,3045,3019(\mathrm{~m}, \mathrm{~m}, \mathrm{w}, \mathrm{Ar}-\mathrm{H}), 2978,2964(\mathrm{~m}, \mathrm{w}, \mathrm{C}-$ H) $1632,1593,1564$ (s, s, m, C=N, C=C), $1471\left(\mathrm{~m}, \mathrm{C}-\mathrm{H}_{\text {def }}\right), 1304$ (m), $1011(\mathrm{~m})$. IR (PE, cm $\left.{ }^{-1}\right): \tilde{v}=560(\mathrm{~m}), 542(\mathrm{~m}), 503(\mathrm{~m}), 495$ (m), 451 (m), 419 (m), 397 (w), 328 (w, Fe-N), 295 (m, Fe-N imine $_{\text {), }}$ 251 (vs, $\mathrm{Fe}-\mathrm{Cl}), 214$ (w), $202(\mathrm{w}), 146(\mathrm{~m}, \mathrm{Fe}-\mathrm{Cl})$. Further $\tilde{v}(\mathrm{Fe}-$ $\mathrm{N})$ bands could not be identified. UV/Vis $\left(\mathrm{CH}_{2} \mathrm{Cl}_{2}\right): \lambda_{\max }(\varepsilon)=653$ (1290). $\mathrm{C}_{24.5} \mathrm{H}_{19} \mathrm{Cl}_{3} \mathrm{FeN}_{4}$ (531.65): calcd. C 55.35, H 3.60, N 10.54; found C 55.24, H 3.75, N $10.58(\%)$.

Dichloro[ $N, N^{\prime}$-(6,6'-dimethylbiphenyl-2,2'-diyl)bis(2-pyridylmethyl)diimine]iron(II) (8): Following the general procedure, $2(2.10 \mathrm{~g}$, $5.38 \mathrm{mmol})$ and $\mathrm{FeCl}_{2}(668 \mathrm{mg}, 5.27 \mathrm{mmol})$ yielded turquoise 8 $(2.54 \mathrm{~g}, 4.91 \mathrm{mmol}, 93 \%)$. SQUID: $\mu_{\mathrm{eff}}=5.47 \mu_{\mathrm{B}} \cdot{ }^{1} \mathrm{H}$ NMR $\left(600 \mathrm{MHz} \mathrm{CDCl}_{3}, \mathrm{ppm}\right): \delta=-7.62\left(\mathrm{~s}, \Delta v_{1 / 2}=30.3 \mathrm{~Hz}, 2 \mathrm{H} ; 4-\mathrm{H} /\right.$ $4^{\prime}-\mathrm{H}$ or $5-\mathrm{H} / 5^{\prime}-\mathrm{H}$ or $\left.4^{\prime \prime}-\mathrm{H}\right),-6.72\left(\mathrm{~s}, \Delta v_{1 / 2}=28.7 \mathrm{~Hz}, 6 \mathrm{H} ; \mathrm{CH}_{3}\right)$, $-2.65\left(\mathrm{~s}, \Delta v_{1 / 2}=149 \mathrm{~Hz}, 2 \mathrm{H} ; 3-\mathrm{H} / 3^{\prime}-\mathrm{H}\right), 11.35\left(\mathrm{~s}, \Delta v_{1 / 2}=36.3 \mathrm{~Hz}\right.$, $2 \mathrm{H} ; 4-\mathrm{H} / 4^{\prime}-\mathrm{H}$ or $5-\mathrm{H} / 5^{\prime}-\mathrm{H}$ or $\left.4^{\prime \prime}-\mathrm{H}\right), 17.08\left(\mathrm{~s}, \Delta v_{1 / 2}=42.1 \mathrm{~Hz}, 2\right.$
$\mathrm{H}$; $4-\mathrm{H} / 4^{\prime}-\mathrm{H}$ or $5-\mathrm{H} / 5^{\prime}-\mathrm{H}$ or $\left.4^{\prime \prime}-\mathrm{H}\right), 52.77\left(\mathrm{~s}, \Delta v_{1 / 2}=66.4 \mathrm{~Hz}, 2 \mathrm{H}\right.$; $3^{\prime \prime}-\mathrm{H}$ or $\left.5^{\prime \prime}-\mathrm{H}\right), 54.20\left(\mathrm{~s}, \Delta v_{1 / 2}=56.6 \mathrm{~Hz}, 2 \mathrm{H} ; 3^{\prime \prime}-\mathrm{H}\right.$ or $\left.5^{\prime \prime}-\mathrm{H}\right)$, $116.21\left(\mathrm{~s}, \Delta v_{1 / 2}=520 \mathrm{~Hz}, 2 \mathrm{H} ; 6^{\prime \prime}-\mathrm{H}\right), 180.74\left(\mathrm{~s}, \Delta v_{1 / 2}=172 \mathrm{~Hz}, 2\right.$ $\mathrm{H} ; \mathrm{N}=\mathrm{CH}) .{ }^{13} \mathrm{C} \mathrm{NMR}\left(151 \mathrm{MHz}, \mathrm{CDCl}_{3}, \mathrm{ppm}\right): \delta=-181.44,0.41$, $39.30\left(\mathrm{CH}_{3}\right), 71.79\left(\mathrm{C}-4 / \mathrm{C}-4^{\prime}\right.$ or $\mathrm{C}-5 / \mathrm{C}-5^{\prime}$ or $\left.\mathrm{C}-4^{\prime \prime}\right), 80.22,157.30$ (C-4/C-4' or C-5/C-5' or C-4' $), 194.91$ (C-4/C-4' or C-5/C-5' or C-4" $), 195.76,199.13,232.31,418.95,533.17,908.63(\mathrm{C}=\mathrm{N})$. IR $\left(\mathrm{KBr}, \mathrm{cm}^{-1}\right): \tilde{\mathrm{v}}=3065,3012(\mathrm{w}, \mathrm{w}, \mathrm{Ar}-\mathrm{H}), 2962,2916,2850(\mathrm{w}, \mathrm{w}$, w, C-H), 1627, 1594, $1563(\mathrm{~m}, \mathrm{~s}, \mathrm{~m}, \mathrm{C}=\mathrm{N}, \mathrm{C}=\mathrm{C}), 1475,1450$ (m, $\left.\mathrm{m}, \mathrm{C}-\mathrm{H}_{\text {def }}\right), 1012(\mathrm{~m}) . \mathrm{IR}\left(\mathrm{PE}, \mathrm{cm}^{-1}\right): \tilde{\mathrm{v}}=590(\mathrm{w}), 555(\mathrm{~m}), 536$ (w), $515(\mathrm{~m}), 488(\mathrm{~m}), 474(\mathrm{~m}), 437$ (w), $416(\mathrm{~s}), 386(\mathrm{w}), 337$ (m, $\mathrm{Fe}-\mathrm{N}), 300$ (s, Fe-N $\mathrm{N}_{\text {imine }}$ ), 271 (w), 244 (vs, Fe-Cl), 192 (m, Fe-N), $144(\mathrm{~s}, \mathrm{Fe}-\mathrm{Cl})$, one $\tilde{\mathrm{v}}(\mathrm{Fe}-\mathrm{N})$ was probably hidden by $\tilde{\mathrm{v}}=244 \mathrm{~cm}^{-1}$. UV/Vis $\left(\mathrm{CH}_{2} \mathrm{Cl}_{2}\right): \lambda_{\max }(\varepsilon)=641$ (1140). MS (FAB): $m / z(\%): 516 /$ $518 / 520(11 / 8 / 2)\left[\mathrm{M}^{+}\right], 481 / 483(100 / 43)\left[\mathrm{M}^{+}-\mathrm{Cl}\right], 446(22)[481 /$ 483 - Cl]; for $\mathrm{C}_{26} \mathrm{H}_{22} \mathrm{Cl}_{2} \mathrm{FeN}_{4}$ (517.24). calcd. C 60.38, H 4.29, N 10.83; found C 60.37, H 4.38, N $10.95(\%)$.

Dibromo[ $N, N^{\prime}$-(6, $6^{\prime}$-dimethylbiphenyl-2,2'-diyl)bis(2-pyridylmethyl)diiminejiron(II) (9): Following the general procedure, 2 (506 $\mathrm{mg}$, $1.30 \mathrm{mmol})$ and $\mathrm{FeBr}_{2}(274 \mathrm{mg}, 1.27 \mathrm{mmol})$ yielded blue $9(398 \mathrm{mg}$, $657 \mu \mathrm{mol}, 52 \%) .{ }^{1} \mathrm{H}$ NMR $\left(600 \mathrm{MHz}, \mathrm{CDCl}_{3}, \mathrm{ppm}\right): \delta=-9.14(\mathrm{~s}$, $\Delta v_{1 / 2}=16.4 \mathrm{~Hz}, 2 \mathrm{H} ; 4-\mathrm{H} / 4^{\prime}-\mathrm{H}$ or $5-\mathrm{H} / 5^{\prime}-\mathrm{H}$ or $\left.4^{\prime \prime}-\mathrm{H}\right),-7.09(\mathrm{~s}$, $\left.\Delta v_{1 / 2}=20.1 \mathrm{~Hz}, 6 \mathrm{H} ; \mathrm{CH}_{3}\right),-6.55\left(\mathrm{~s}, \Delta v_{1 / 2}=110 \mathrm{~Hz}, 2 \mathrm{H} ; 3-\mathrm{H} / 3^{\prime}-\right.$ $\mathrm{H}), 11.15\left(\mathrm{~s}, \Delta v_{1 / 2}=20.9 \mathrm{~Hz}, 2 \mathrm{H} ; 4-\mathrm{H} / 4^{\prime}-\mathrm{H}\right.$ or $5-\mathrm{H} / 5^{\prime}-\mathrm{H}$ or $4^{\prime \prime}-$ $\mathrm{H}), 17.43\left(\mathrm{~s}, \Delta v_{1 / 2}=22.0 \mathrm{~Hz}, 2 \mathrm{H} ; 4-\mathrm{H} / 4^{\prime}-\mathrm{H}\right.$ or $5-\mathrm{H} / 5^{\prime}-\mathrm{H}$ or $4^{\prime \prime}-$ $\mathrm{H}), 53.48\left(\mathrm{~s}, \Delta v_{1 / 2}=37.3 \mathrm{~Hz}, 2 \mathrm{H} ; 3^{\prime \prime}-\mathrm{H}\right.$ or $\left.5^{\prime \prime}-\mathrm{H}\right), 57.97\left(\mathrm{~s}, \Delta v_{1 / 2}\right.$ $=34.2 \mathrm{~Hz}, 2 \mathrm{H} ; 3^{\prime \prime}-\mathrm{H}$ or $\left.5^{\prime \prime}-\mathrm{H}\right), 119.70\left(\mathrm{~s}, \Delta v_{1 / 2}=425 \mathrm{~Hz}, 2 \mathrm{H}\right.$; $6^{\prime \prime}-\mathrm{H}$ ), 191.20 (s, $\Delta v_{1 / 2}=128 \mathrm{~Hz}, 2 \mathrm{H}$; $\mathrm{N}=\mathrm{CH}$ ); due to the very low solubility no signals were observed in the ${ }^{13} \mathrm{C}$ NMR spectrum. IR $\left(\mathrm{KBr}, \mathrm{cm}^{-1}\right): \tilde{v}=3089,3057,3015(\mathrm{w}, \mathrm{m}, \mathrm{m}, \mathrm{Ar}-\mathrm{H}), 1636,1598$, $1564(\mathrm{~m}, \mathrm{~m}, \mathrm{~m}, \mathrm{~m}, \mathrm{~m}, \mathrm{C}=\mathrm{N}, \mathrm{C}=\mathrm{C}), 1476,1448\left(\mathrm{~m}, \mathrm{~m}, \mathrm{C}-\mathrm{H}_{\mathrm{def}}\right)$, $1306(\mathrm{~m}), 1217(\mathrm{~m}), 1013(\mathrm{~m})$. IR $\left(\mathrm{PE}_{\mathrm{THF}} \mathrm{cm}^{-1}\right): \tilde{\mathrm{v}}=588(\mathrm{~m}), 557$ (s), $535(\mathrm{w}), 522(\mathrm{w}), 512(\mathrm{w}), 479(\mathrm{~s}), 423(\mathrm{w}), 414(\mathrm{~m}), 371(\mathrm{w})$, $339(\mathrm{~m}, \mathrm{Fe}-\mathrm{N}), 318$ (w), 297 (s, Fe-N imine $_{\text {), }} 269$ (m), 241 (m), 223, $191(\mathrm{~s}, \mathrm{~s}, \mathrm{Fe}-\mathrm{N}), 174$ (s, $\mathrm{Fe}-\mathrm{Br}), 104$ (s, $\mathrm{Fe}-\mathrm{Br})$. UV/Vis $\left(\mathrm{CH}_{2} \mathrm{Cl}_{2}\right)$ : $\lambda_{\max }(\varepsilon)=630(1000) . \mathrm{C}_{26} \mathrm{H}_{22} \mathrm{Br}_{2} \mathrm{FeN}_{4}$ (606.14): calcd. C 51.52, H $3.66, \mathrm{~N} 9.24$; found C 52.07, H 3.63, N $9.19(\%)$.

Dichloro $\left\{N, N^{\prime}\right.$ - $\left(6,6^{\prime}\right.$-dimethylbiphenyl-2,2 -diyl)bis[1-(2-pyridyl)ethane]diimine\}iron(II) (10): Following the general procedure, crude $6\left(1.59 \mathrm{~g}, 1.41 \mathrm{mmol}\right.$, based on $\left.{ }^{1} \mathrm{H} \mathrm{NMR}\right)$ and $\mathrm{FeCl}_{2}(157 \mathrm{mg}$, $1.24 \mathrm{mmol}$ ) yielded blue 10 (608 mg, $1.12 \mathrm{mmol}, 90 \%) .{ }^{1} \mathrm{H}$ NMR ( $\left.600 \mathrm{MHz}, \mathrm{CDCl}_{3}, \mathrm{ppm}\right): \delta=-10.43$ ( $\mathrm{s}, \Delta v_{1 / 2}=16.8 \mathrm{~Hz}$ ( 2 signals), $4 \mathrm{H} ; 3-\mathrm{H} / 3^{\prime}-\mathrm{H}$ and $4-\mathrm{H} / 4^{\prime}-\mathrm{H}$ or $5-\mathrm{H} / 5^{\prime}-\mathrm{H}$ or $\left.4^{\prime \prime}-\mathrm{H}\right),-7.45\left(\mathrm{~s}, \Delta v_{1 / 2}\right.$ $\left.=12.6 \mathrm{~Hz}, 6 \mathrm{H} ; 6-\mathrm{CH}_{3} / 6^{\prime}-\mathrm{CH}_{3}\right), 0.07\left(\mathrm{~s}, \Delta v_{1 / 2}=43.1 \mathrm{~Hz}, 6 \mathrm{H} ; \mathrm{N}=\mathrm{C}-\right.$ $\left.\mathrm{CH}_{3}\right), 10.13\left(\mathrm{~s}, \Delta v_{1 / 2}=21.4 \mathrm{~Hz}, 2 \mathrm{H} ; 4-\mathrm{H} / 4^{\prime}-\mathrm{H}\right.$ or $5-\mathrm{H} / 5^{\prime}-\mathrm{H}$ or $4^{\prime \prime}-$ $\mathrm{H}), 17.19\left(\mathrm{~s}, \Delta v_{1 / 2}=22.9 \mathrm{~Hz}, 2 \mathrm{H} ; 4-\mathrm{H} / 4^{\prime}-\mathrm{H}\right.$ or $5-\mathrm{H} / 5^{\prime}-\mathrm{H}$ or $4^{\prime \prime}{ }^{\prime}$ $\mathrm{H}), 52.32\left(\mathrm{~s}, \Delta v_{1 / 2}=38.0 \mathrm{~Hz}, 2 \mathrm{H} ; 3^{\prime \prime}-\mathrm{H}\right.$ or $\left.5^{\prime \prime}-\mathrm{H}\right), 71.49\left(\mathrm{~s}, \Delta v_{1 / 2}\right.$ $=48.0 \mathrm{~Hz}, 2 \mathrm{H} ; 3^{\prime \prime}-\mathrm{H}$ or $\left.5^{\prime \prime}-\mathrm{H}\right), 112.82\left(\mathrm{~s}, \Delta v_{1 / 2}=552 \mathrm{~Hz}, 2 \mathrm{H}\right.$; $\left.6^{\prime \prime}-\mathrm{H}\right) .{ }^{13} \mathrm{C}$ NMR $\left(151 \mathrm{MHz}, \mathrm{CDCl}_{3}, \mathrm{ppm}\right): \delta=-344.57(\mathrm{~N}=\mathrm{C}-$ $\left.\mathrm{CH}_{3}\right),-169.06,-10.31,30.66,58.11,66.02\left(\mathrm{C}-3^{\prime \prime}\right.$ or $\left.\mathrm{C}-5^{\prime \prime}\right), 163.12$, $185.37,194.82,198.83\left(\mathrm{C}-4 / \mathrm{C}-4^{\prime}\right.$ or $\mathrm{C}-5 / \mathrm{C}-5^{\prime}$ or $\left.\mathrm{C}-4^{\prime \prime}\right), 207.07$, 347.97, 449.81, 522.34. IR $\left(\mathrm{KBr}, \mathrm{cm}^{-1}\right): \tilde{v}=3091,3057,3021(\mathrm{~m}$, $\mathrm{m}, \mathrm{m}, \mathrm{Ar}-\mathrm{H}$ ), 2985, 2965, 2946, 2921, 2860 (w, w, w, m, w, C-H), $1629,1593,1565(\mathrm{~m}, \mathrm{~m}, \mathrm{~m}, \mathrm{C}=\mathrm{N}, \mathrm{C}=\mathrm{C}), 1436\left(\mathrm{~m}, \mathrm{C}-\mathrm{H}_{\mathrm{def}}\right), 1366$ $(\mathrm{m}), 1318(\mathrm{~m}), 1258(\mathrm{~m}), 1009(\mathrm{~m}) . \mathrm{IR}\left(\mathrm{PE}, \mathrm{cm}^{-1}\right): \tilde{\mathrm{v}}=595(\mathrm{w}), 590$ $(\mathrm{m}), 575(\mathrm{~m}), 569(\mathrm{~m}), 559(\mathrm{~m}), 537(\mathrm{~m}), 420(\mathrm{~m}), 372(\mathrm{w}), 345(\mathrm{~m}$, $\mathrm{Fe}-\mathrm{N}), 245,235$ (s, s, Fe-N, Fe-Cl), 192 (w), $179(\mathrm{~m}, \mathrm{Fe}-\mathrm{N}), 150$ (w), $141(\mathrm{~m}, \mathrm{Fe}-\mathrm{Cl})$, one $(\mathrm{Fe}-\mathrm{N})$ signal was probably hidden by peaks at $\tilde{\mathrm{v}}=245$ and $235 \mathrm{~cm}^{-1}$. UV/Vis $\left(\mathrm{CH}_{2} \mathrm{Cl}_{2}\right): \lambda_{\max }(\varepsilon)=625$ (1430). $\mathrm{C}_{28} \mathrm{H}_{26} \mathrm{Cl}_{2} \mathrm{FeN}_{4}$ (545.29): calcd. C 61.67, H 4.81, N 10.27; found C 61.78, H 4.95, N $10.23(\%)$.

Dichloro[ $N, N^{\prime}$ - $\left(6,6^{\prime}\right.$-dimethylbiphenyl-2,2'-diyl)bis(2-pyridylmethyl)diimine]cobalt(II) (11): Following the general procedure, 2 (512 mg, 
$1.31 \mathrm{mmol})$ and $\mathrm{CoCl}_{2}(167 \mathrm{mg}, 1.29 \mathrm{mmol})$ yielded light brown $11(542 \mathrm{mg}, 1.04 \mathrm{mmol}, 81 \%)$. SQUID: $\mu_{\mathrm{eff}}=4.96 \mu_{\mathrm{B}} \cdot{ }^{1} \mathrm{H} \mathrm{NMR}$ $\left(600 \mathrm{MHz}, \mathrm{CDCl}_{3}, \mathrm{ppm}\right): \delta=-16.17\left(\mathrm{~s}, \Delta v_{1 / 2}=137 \mathrm{~Hz}, 2 \mathrm{H} ; 3-\mathrm{H} /\right.$ $\left.3^{\prime}-\mathrm{H}\right),-10.57$ (s, $\Delta v_{1 / 2}=14.1 \mathrm{~Hz}, 2 \mathrm{H} ; 4-\mathrm{H} / 4^{\prime}-\mathrm{H}$ or $5-\mathrm{H} / 5^{\prime}-\mathrm{H}$ or $4^{\prime \prime}$ $\mathrm{H}),-2.17\left(\mathrm{~s}, \Delta v_{1 / 2}=11.5 \mathrm{~Hz}, 6 \mathrm{H} ; \mathrm{CH}_{3}\right), 6.46\left(\mathrm{~s}, \Delta v_{1 / 2}=18.7 \mathrm{~Hz}, 2\right.$ $\mathrm{H} ; 4-\mathrm{H} / 4^{\prime}-\mathrm{H}$ or $5-\mathrm{H} / 5^{\prime}-\mathrm{H}$ or $\left.4^{\prime \prime}-\mathrm{H}\right), 12.94\left(\mathrm{~s}, \Delta v_{1 / 2}=22.8 \mathrm{~Hz}, 2 \mathrm{H}\right.$; $4-\mathrm{H} / 4^{\prime}-\mathrm{H}$ or $5-\mathrm{H} / 5^{\prime}-\mathrm{H}$ or $\left.4^{\prime \prime}-\mathrm{H}\right), 38.15\left(\mathrm{~s}, \Delta v_{1 / 2}=39.8 \mathrm{~Hz}, 2 \mathrm{H} ; 3^{\prime \prime}-\right.$ $\mathrm{H}$ or $\left.5^{\prime \prime}-\mathrm{H}\right), 54.23\left(\mathrm{~s}, \Delta v_{1 / 2}=54.2 \mathrm{~Hz}, 2 \mathrm{H} ; 3^{\prime \prime}-\mathrm{H}\right.$ or $\left.5^{\prime \prime}-\mathrm{H}\right), 70.38$ (s, $\left.\Delta v_{1 / 2}=472 \mathrm{~Hz}, 2 \mathrm{H} ; 6^{\prime \prime}-\mathrm{H}\right), 230.67\left(\mathrm{~s}, \Delta v_{1 / 2}=215 \mathrm{~Hz}, 2 \mathrm{H}\right.$; $\mathrm{N}=\mathrm{CH}) .{ }^{13} \mathrm{C}$ NMR $\left(151 \mathrm{MHz}, \mathrm{CDCl}_{3}, \mathrm{ppm}\right): \delta=15.75,51.37(\mathrm{C}-$ $4 / \mathrm{C}-4^{\prime}$ or $\mathrm{C}-5 / \mathrm{C}-5^{\prime}$ or $\left.\mathrm{C}-4^{\prime \prime}\right), 53.44\left(\mathrm{CH}_{3}\right), 73.51,130.72\left(\mathrm{C}-4 / \mathrm{C}-4^{\prime}\right.$ or $\mathrm{C}-5 / \mathrm{C}-5^{\prime}$ or $\left.\mathrm{C}-4^{\prime \prime}\right), 219.72\left(\mathrm{C}-4 / \mathrm{C}-4^{\prime}\right.$ or $\mathrm{C}-5 / \mathrm{C}-5^{\prime}$ or $\left.\mathrm{C}-4^{\prime \prime}\right)$, $225.22,258.22,296.55,411.81$, other expected ${ }^{13} \mathrm{C}$ signals were not detectable due to the low solubility and the low intensity of the broad ${ }^{13} \mathrm{C}$ signals. IR $\left(\mathrm{KBr}, \mathrm{cm}^{-1}\right): \tilde{\mathrm{v}}=3093,3061,3042,3013(\mathrm{w}$, $\mathrm{m}, \mathrm{w}, \mathrm{m}, \mathrm{Ar}-\mathrm{H}$ ), 1639, 1598, 1568 (s, s, m, C=N, C=C), 1479, 1448 (m, s, C-H def $), 1307$ (s), 1219 (s), 1014 (s). IR (PE, cm $\left.{ }^{-1}\right): \tilde{v}=591$ (m), $558(\mathrm{~m}), 496(\mathrm{~m}), 484(\mathrm{~s}), 430(\mathrm{~m}), 379(\mathrm{w}), 341,308(\mathrm{~m}, \mathrm{~s}$, $\mathrm{Co}-\mathrm{N}), 270(\mathrm{~m}), 242(\mathrm{~s}, \mathrm{Co}-\mathrm{Cl}), 225,181(\mathrm{~m}, \mathrm{~m}, \mathrm{Co}-\mathrm{N}), 135(\mathrm{~s}$, $\mathrm{Co}-\mathrm{Cl})$. UV/Vis $\left(\mathrm{CH}_{2} \mathrm{Cl}_{2}\right)$ : no maxima observed. $\mathrm{C}_{26} \mathrm{H}_{22} \mathrm{Cl}_{2} \mathrm{CoN}_{4}$ (520.33): calcd. C 60.02, H 4.26, N 10.77; found C 59.32, H 4.47, N $10.64(\%)$.

Dichloro $\left\{N, N^{\prime}-\left(6,6^{\prime}\right.\right.$-dimethylbiphenyl-2,2' -diyl)bis[(6-methyl-2-pyridyl)methyl]diimine; iron(I) THF (12.THF): According to the general procedure for complexes 7-11, ligand $3(1.04 \mathrm{~g}, 2.48 \mathrm{mmol})$ and $\mathrm{FeCl}_{2}$ (308 mg, $2.43 \mathrm{mmol}$ ) yielded brown $15 . \mathrm{THF}$ (891 mg, $1.44 \mathrm{mmol}, 59 \%) .{ }^{1} \mathrm{H}$ NMR $\left(250 \mathrm{MHz}, \mathrm{CDCl}_{3}, \mathrm{ppm}\right): \delta=-11.39$ (s, $\left.\Delta v_{1 / 2}=325 \mathrm{~Hz}\right),-4.91\left(\mathrm{~s}, \Delta v_{1 / 2}=75.3 \mathrm{~Hz}\right), 3.45\left(\mathrm{~s}, \Delta v_{1 / 2}=\right.$ 94.2 Hz). MS (FAB): $m / z(\%): 509 / 511(100 / 50)\left[\mathrm{M}^{+}-\mathrm{THF}-\mathrm{Cl}\right]$, 474 (38) [509/511 - Cl], $406(77), 371(71) ; \mathrm{C}_{32} \mathrm{H}_{34} \mathrm{Cl}_{2} \mathrm{FeN}_{4} \mathrm{O}$ (617.40): calcd. C 62.25, H 5.55, N 9.07; found: C 62.42, H 5.41, N $8.99(\%)$.

Dichloro $\left\{N, N^{\prime}-\left(6,6^{\prime}\right.\right.$-dimethylbiphenyl-2,2' -diyl)bis[(6-methyl-2-pyridyl)methyl]diimine; iron(II) (12): A solution of ligand 3 (1.01 g, $2.42 \mathrm{mmol})$ in $\mathrm{CH}_{2} \mathrm{Cl}_{2}(30 \mathrm{~mL})$ was added to a suspension of $\mathrm{FeCl}_{2}$ (301 $\mathrm{mg}, 2.37 \mathrm{mmol})$ in $\mathrm{CH}_{2} \mathrm{Cl}_{2}(30 \mathrm{~mL})$. After 2 days, the reaction mixture was filtered, the filtrate evaporated to dryness and the residue suspended in diethyl ether $(20 \mathrm{~mL})$. The solid was collected by filtration, washed with diethyl ether $(3 \times 5 \mathrm{~mL})$ and dried in vacuo. Yield $872 \mathrm{mg}(1.60 \mathrm{mmol}, 68 \%)$ of brown 15. SQUID $\left(\mathrm{CH}_{2} \mathrm{Cl}_{2}\right)$ : a) $\mu_{\text {eff }}=3.41 \mu_{\mathrm{B}}$; SQUID (diethyl ether): ${ }^{[\mathrm{a}]} \mu_{\mathrm{eff}}=5.23 \mu_{\mathrm{B}}$. IR (PE, diethyl ether, $\left.\mathrm{cm}^{-1}\right) \mathrm{:}^{[\mathrm{a}]} \tilde{\mathrm{v}}=595(\mathrm{w}), 580(\mathrm{~m}), 568(\mathrm{w}), 560(\mathrm{~m}), 550$ $(\mathrm{w}), 541(\mathrm{~m}), 526(\mathrm{~m}), 488(\mathrm{w}), 477(\mathrm{~m}), 444(\mathrm{~m}), 435(\mathrm{w}), 362(\mathrm{~m})$, $327(\mathrm{~s}), 307(\mathrm{~m}), 269(\mathrm{~m}), 202(\mathrm{~m})$. IR $\left(\mathrm{PE}, \mathrm{CH}_{2} \mathrm{Cl}_{2}, \mathrm{~cm}^{-1}\right):^{[\mathrm{a}]} \tilde{\mathrm{v}}=$ $586(\mathrm{~m}), 565(\mathrm{~m}), 541(\mathrm{~m}), 528(\mathrm{~m}), 512(\mathrm{~m}), 448(\mathrm{~m}), 431(\mathrm{w}), 408$ (w), 367 (vs), 319 (vs), 268 (m). $\mathrm{C}_{28} \mathrm{H}_{26} \mathrm{Cl}_{2} \mathrm{FeN}_{4}$ (545.29): calcd. C 61.67, H 4.81, N 10.27; found C 61.82, H 5.01, N $10.31(\%)$. ${ }^{[a]}$

Dimethyl[ $N, N^{\prime}-\left(6,6^{\prime}\right.$-dimethylbiphenyl-2,2'-diyl) bis(2-pyridylmethyl)diiminejiron(II) (13): Complex 8 (700 $\mathrm{mg}, 1.35 \mathrm{mmol}$ ) was suspended in THF $(20 \mathrm{~mL})$ and cooled to $-78^{\circ} \mathrm{C}$. At this temperature $\mathrm{MeMgCl}(451 \mu \mathrm{L}$ of a $3.0 \mathrm{M}$ solution in THF, $1.35 \mathrm{mmol})$ was added and the reaction mixture was allowed to warm to room temperature within $3 \mathrm{~h}$. After stirring overnight, solvent was removed by distillation and the residue extracted with toluene $(40 \mathrm{~mL})$. Evaporating the solvent yielded complex 13 as a brown powder (289 mg, $607 \mu \mathrm{mol}, 45 \%) .{ }^{1} \mathrm{H}$ NMR $\left(600 \mathrm{MHz}, \mathrm{CD}_{2} \mathrm{Cl}_{2}, \mathrm{ppm}\right): \delta$ $=-0.47\left(\mathrm{~s}, 3 \mathrm{H}, \mathrm{Fe}-\mathrm{CH}_{3, \mathrm{ax}}\right), 1.15\left(\mathrm{~s}, 3 \mathrm{H}, \mathrm{Fe}-\mathrm{CH}_{3, \mathrm{eq}}\right), 2.04(\mathrm{~s}, 3 \mathrm{H}$, $\left.6-\mathrm{CH}_{3}\right), 2.09\left(\mathrm{~s}, 3 \mathrm{H}, 6^{\prime}-\mathrm{CH}_{3}\right), 6.70\left[\mathrm{~d},{ }^{3} J(\mathrm{H}-\mathrm{H})=7.6 \mathrm{~Hz}, 1 \mathrm{H} ; 3^{\prime}-\right.$ $\mathrm{H}], 6.72\left[\mathrm{~d},{ }^{3} J(\mathrm{H}-\mathrm{H})=7.9 \mathrm{~Hz}, 1 \mathrm{H} ; 3-\mathrm{H}\right], 6.88\left[\mathrm{t},{ }^{3} J(\mathrm{H}-\mathrm{H})=\right.$ $\left.6.5 \mathrm{~Hz}, 1 \mathrm{H} ; 5^{\prime \prime \prime}-\mathrm{H}\right], 6.99\left[\mathrm{t},{ }^{3} J(\mathrm{H}-\mathrm{H})=7.6 \mathrm{~Hz}, 1 \mathrm{H} ; 4-\mathrm{H}\right], 7.03[\mathrm{~d}$, $\left.{ }^{3} J(\mathrm{H}-\mathrm{H})=7.6 \mathrm{~Hz}, 1 \mathrm{H} ; 5^{\prime}-\mathrm{H}\right], 7.05\left[\mathrm{~d},{ }^{3} J(\mathrm{H}-\mathrm{H})=5.6 \mathrm{~Hz}, 1 \mathrm{H}\right.$; $\left.6^{\prime \prime \prime}-\mathrm{H}\right], 7.09\left[\mathrm{~d},{ }^{3} J(\mathrm{H}-\mathrm{H})=7.3 \mathrm{~Hz}, 1 \mathrm{H} ; 5-\mathrm{H}\right], 7.19\left[\mathrm{t},{ }^{3} J(\mathrm{H}-\mathrm{H})=\right.$ $\left.7.6 \mathrm{~Hz}, 1 \mathrm{H} ; 4^{\prime}-\mathrm{H}\right], 7.30\left[\mathrm{t},{ }^{3} J(\mathrm{H}-\mathrm{H})=7.9 \mathrm{~Hz}, 1 \mathrm{H} ; 4^{\prime \prime \prime}-\mathrm{H}\right], 7.40$ $\left[\mathrm{t},{ }^{3} J(\mathrm{H}-\mathrm{H})=6.3 \mathrm{~Hz}, 1 \mathrm{H} ; 5^{\prime \prime}-\mathrm{H}\right], 7.47\left[\mathrm{t},{ }^{3} J(\mathrm{H}-\mathrm{H})=7.5 \mathrm{~Hz}, 1 \mathrm{H}\right.$; $\left.4^{\prime \prime}-\mathrm{H}\right], 7.51\left[\mathrm{~d},{ }^{3} J(\mathrm{H}-\mathrm{H})=7.9 \mathrm{~Hz}, 1 \mathrm{H} ; 3^{\prime \prime \prime}-\mathrm{H}\right], 7.70\left[\mathrm{~d},{ }^{3} J(\mathrm{H}-\mathrm{H})\right.$ $\left.=8.2 \mathrm{~Hz}, 1 \mathrm{H} ; 3^{\prime \prime}-\mathrm{H}\right], 8.63\left(\mathrm{~s}, 1 \mathrm{H}, 2^{\prime}-\mathrm{N}=\mathrm{CH}\right), 8.87\left[\mathrm{~d},{ }^{3} J(\mathrm{H}-\mathrm{H})=\right.$ $\left.5.9 \mathrm{~Hz}, 1 \mathrm{H} ; 6^{\prime \prime}-\mathrm{H}\right], 9.68(\mathrm{~s}, 1 \mathrm{H}, 2-\mathrm{N}=\mathrm{CH}) .{ }^{13} \mathrm{C} \mathrm{NMR}(151 \mathrm{MHz}$, $\left.\mathrm{CD}_{2} \mathrm{Cl}_{2}, \mathrm{ppm}\right): \delta=18.13\left(\mathrm{Fe}-\mathrm{CH}_{3, \mathrm{ax}}\right), 19.75\left(6^{\prime}-\mathrm{CH}_{3}\right), 20.43(6-$ $\left.\mathrm{CH}_{3}\right), 22.22\left(\mathrm{Fe}-\mathrm{CH}_{3, \mathrm{eq}}\right), 115.18\left(\mathrm{C}-3^{\prime}\right), 115.87\left(\mathrm{C}-5^{\prime \prime}\right), 118.90(\mathrm{C}-$ $\left.5^{\prime \prime \prime}\right), 121.84(\mathrm{C}-3), 123.57\left(\mathrm{C}-3^{\prime \prime}\right), 124.80\left(\mathrm{C}-3^{\prime \prime \prime}\right), 126.61\left(\mathrm{C}-5^{\prime}\right)$, $126.66\left(\mathrm{C}-5, \mathrm{C}^{\prime} 4^{\prime}\right), 128.25,128.27$ (C-4, C-4' $), 128.52$ (C-1), 129.17 $\left(\mathrm{C}-1^{\prime}\right), 130.28\left({\mathrm{C}-4^{\prime \prime \prime}}^{\prime \prime}, 137.19\left(\mathrm{C}-6^{\prime}\right), 139.04(\mathrm{C}-6), 148.28\left(\mathrm{C}-6^{\prime \prime \prime}\right)\right.$, $148.54(2-\mathrm{N}=\mathrm{C}), 149.90\left(2^{\prime}-\mathrm{N}=\mathrm{C}\right), 151.85\left(\mathrm{C}^{\prime \prime} 6^{\prime \prime}\right), 152.27(\mathrm{C}-2)$, $154.41\left({\mathrm{C}-2^{\prime}}^{\prime}\right), 157.48\left(\mathrm{C}-2^{\prime \prime \prime}\right), 157.92\left(\mathrm{C}-2^{\prime \prime}\right)$. IR $\left(\mathrm{KBr}, \mathrm{cm}^{-1}\right): \tilde{\mathrm{v}}=$ 3054, 3008 (m, w, Ar-H), 2963, 2916, 2856 (w, w, m, C-H), 1584, $1567(\mathrm{~s}, \mathrm{~s}, \mathrm{C}=\mathrm{N}, \mathrm{C}=\mathrm{C}), 1467,1441\left(\mathrm{~s}, \mathrm{~s}, \mathrm{C}-\mathrm{H}_{\text {def }}\right), 1407(\mathrm{~s}), 997(\mathrm{~m})$, $991(\mathrm{~m})$. IR $\left(\mathrm{PE}, \mathrm{cm}^{-1}\right): \tilde{v}=588(\mathrm{~m}), 551(\mathrm{w}), 539(\mathrm{w}), 520(\mathrm{~s})$, $476(\mathrm{~s}), 452(\mathrm{~m}), 405(\mathrm{~m})$. UV/Vis $(\mathrm{THF}): \lambda_{\max }(\varepsilon)=834(3200)$. $\mathrm{C}_{28} \mathrm{H}_{28} \mathrm{FeN}_{4}$ (476.40): calcd. C 70.59, H 5.92, N 11.76; found $\mathrm{C}$ 67.48, H $5.49, \mathrm{~N} 11.15(\%)$.

$\mathrm{Di}\left(\right.$ tent-butylisocyano) $\left[N, N^{\prime}-\left(6,6^{\prime}\right.\right.$-dimethylbiphenyl-2,2'-diyl) bis(2-pyridylmethyl)diimine]iron(II)-bis(trifluoromethanesulfonate) (14): To a suspension of $8(300 \mathrm{mg}, 580 \mu \mathrm{mol})$ in THF $(20 \mathrm{~mL})$ was added tert-butylisocyanide $(131 \mu \mathrm{L}, 96.4 \mathrm{mg}, 1.16 \mathrm{mmol})$ and a solution of AgOTf $(298 \mathrm{mg}, 1.16 \mathrm{mmol})$ in THF (15 mL). A red suspension formed immediately. After stirring overnight the solvent was evaporated and the residue dissolved in $\mathrm{CH}_{2} \mathrm{Cl}_{2}(40 \mathrm{~mL})$. The solution was filtered via cannula and the solvents evaporated to dryness and the solid residue suspended in diethyl ether $(20 \mathrm{~mL})$. The solid was collected by filtration and washed with diethyl ether $(3 \times 5 \mathrm{~mL})$. Yield $407 \mathrm{mg}(447 \mu \mathrm{mol}, 77 \%)$ orange $14 .{ }^{1} \mathrm{H}$ NMR $\left(600 \mathrm{MHz}, \mathrm{CDCl}_{3}, \mathrm{ppm}\right): \delta=1.04\left[\mathrm{~s}, 9 \mathrm{H} ; \mathrm{C}\left(\mathrm{CH}_{3}\right)_{3, \mathrm{ax}}\right], 1.57[\mathrm{~s}, 9$ $\mathrm{H} ; \mathrm{C}\left(\mathrm{CH}_{3}\right)_{3, \mathrm{eq}}$ ], $2.03\left(\mathrm{~s}, 3 \mathrm{H}, 6-\mathrm{CH}_{3}\right), 2.22\left(\mathrm{~s}, 3 \mathrm{H}, 6^{\prime}-\mathrm{CH}_{3}\right), 6.85$ [d, $\left.{ }^{3} J(\mathrm{H}-\mathrm{H})=7.9 \mathrm{~Hz}, 1 \mathrm{H} ; 3-\mathrm{H}\right], 7.05\left[\mathrm{~d},{ }^{3} J(\mathrm{H}-\mathrm{H})=7.9 \mathrm{~Hz}, 1 \mathrm{H} ; 3^{\prime}-\right.$ $\mathrm{H}], 7.14\left[\mathrm{t},{ }^{3} J(\mathrm{H}-\mathrm{H})=7.9 \mathrm{~Hz}, 1 \mathrm{H} ; 4-\mathrm{H}\right], 7.34\left[\mathrm{~d},{ }^{3} J(\mathrm{H}-\mathrm{H})=\right.$ $\left.7.9 \mathrm{~Hz}, 2 \mathrm{H} ; 5-\mathrm{H}, 5^{\prime}-\mathrm{H}\right], 7.45\left[\mathrm{t},{ }^{3} J(\mathrm{H}-\mathrm{H})=7.8 \mathrm{~Hz}, 1 \mathrm{H} ; 4^{\prime}-\mathrm{H}\right]$, $7.58\left[\mathrm{t},{ }^{3} J(\mathrm{H}-\mathrm{H})=6.2 \mathrm{~Hz}, 1 \mathrm{H} ; 5^{\prime \prime \prime}-\mathrm{H}\right], 7.83\left[\mathrm{~d},{ }^{3} J(\mathrm{H}-\mathrm{H})=5.3 \mathrm{~Hz}\right.$, $\left.1 \mathrm{H} ; 6^{\prime \prime \prime}-\mathrm{H}\right], 7.89\left[\mathrm{t},{ }^{3} J(\mathrm{H}-\mathrm{H})=6.5 \mathrm{~Hz}, 1 \mathrm{H} ; 5^{\prime \prime}-\mathrm{H}\right], 7.98\left[\mathrm{t},{ }^{3} J(\mathrm{H}-\right.$ $\left.\mathrm{H})=7.3 \mathrm{~Hz}, 1 \mathrm{H} ; 4^{\prime \prime \prime}-\mathrm{H}\right], 8.15\left[\mathrm{t},{ }^{3} J(\mathrm{H}-\mathrm{H})=7.3 \mathrm{~Hz}, 1 \mathrm{H} ; 4^{\prime \prime}-\mathrm{H}\right]$, $8.23\left[\mathrm{~d},{ }^{3} J(\mathrm{H}-\mathrm{H})=7.6 \mathrm{~Hz}, 1 \mathrm{H} ; 3^{\prime \prime \prime}-\mathrm{H}\right], 8.50\left(\mathrm{~s}, 1 \mathrm{H}, 2^{\prime}-\mathrm{N}=\mathrm{CH}\right)$, $8.58\left[\mathrm{~d},{ }^{3} J(\mathrm{H}-\mathrm{H})=7.6 \mathrm{~Hz}, 1 \mathrm{H} ; 3^{\prime \prime}-\mathrm{H}\right], 8.89\left[\mathrm{~d},{ }^{3} J(\mathrm{H}-\mathrm{H})=5.0 \mathrm{~Hz}\right.$, $\left.1 \mathrm{H} ; 6^{\prime \prime}-\mathrm{H}\right], 9.37$ (s, $\left.1 \mathrm{H}, 2-\mathrm{N}=\mathrm{CH}\right) .{ }^{13} \mathrm{C}$ NMR $\left(151 \mathrm{MHz}, \mathrm{CDCl}_{3}\right.$, ppm): $\delta=20.03\left(6^{\prime}-\mathrm{CH}_{3}\right), 20.29\left(6-\mathrm{CH}_{3}\right), 30.06\left[\mathrm{C}\left(\mathrm{CH}_{3}\right)_{3, \mathrm{ax}}\right], 30.54$ $\left[\mathrm{C}\left(\mathrm{CH}_{3}\right)_{3, \text { eq }}\right], 58.91,60.70\left[\mathrm{C}\left(\mathrm{CH}_{3}\right)_{3}\right], 115.37\left(\mathrm{C}-3^{\prime}\right), 122.56(\mathrm{C}-3)$, $126.54\left(\mathrm{C}-1^{\prime}\right), 129.03\left(\mathrm{C}-4^{\prime}, \mathrm{C}-5^{\prime \prime \prime}\right), 129.58(\mathrm{C}-1), 129.81\left(\mathrm{C}-3^{\prime \prime \prime}\right)$,

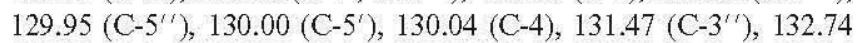
(C-5), $139.18\left(\mathrm{C}-4^{\prime \prime \prime}\right), 139.27\left(\mathrm{C}-4^{\prime \prime}\right), 140.00\left(\mathrm{C}-6^{\prime}\right), 140.26(\mathrm{C}-6)$, $143.79(\mathrm{C}-2), 151.44\left(\mathrm{C}-2^{\prime}\right), 153.09\left(\mathrm{C}-6^{\prime \prime \prime}\right), 156.03\left(\mathrm{C}-2^{\prime \prime \prime}\right), 156.19$ $\left(\mathrm{C}-6^{\prime \prime}\right), 157.01\left(\mathrm{C}-2^{\prime \prime}\right), 169.08(2-\mathrm{N}=\mathrm{C}), 171.86\left(2^{\prime}-\mathrm{N}=\mathrm{C}\right)$, the $\mathrm{CF}_{3}$ and $\mathrm{C} \equiv \mathrm{N}$ signals could not be detected. ${ }^{19} \mathrm{~F}$ NMR $(376 \mathrm{MHz}$, $\left.\mathrm{CDCl}_{3}, \mathrm{ppm}\right): \delta=-77.44$. IR $\left(\mathrm{KBr}, \mathrm{cm}^{-1}\right): \tilde{\mathrm{v}}=3075,3033(\mathrm{w}, \mathrm{w}$, $\mathrm{Ar}-\mathrm{H}), 2984,2939,2879$ (m, w, w, C-H), 2184, $2160(\mathrm{~s}, \mathrm{~s}, \mathrm{C} \equiv \mathrm{N})$, $1619,1603,1594,1569(\mathrm{~m}, \mathrm{~m}, \mathrm{~m}, \mathrm{~m}, \mathrm{C}=\mathrm{N}, \mathrm{C}=\mathrm{C}), 1477,1462,1451$ $\left(\mathrm{m}, \mathrm{w}, \mathrm{m}, \mathrm{C}-\mathrm{H}_{\text {def }}\right), 1276,1262,1223,1149$ (s, s, s, s, S=O, C-F), $1031(\mathrm{~s}), 636(\mathrm{~s})$. IR $\left(\mathrm{PE}, \mathrm{cm}^{-1}\right): \check{\mathrm{v}}=571(\mathrm{~s}), 550(\mathrm{~m}), 516(\mathrm{~s}), 464$ (m), $445(\mathrm{~m}), 394(\mathrm{~m}), 348(\mathrm{~m}), 320(\mathrm{~m}), 293(\mathrm{~m}), 270(\mathrm{~m}), 227(\mathrm{w})$, 209 (m), 188 (w), 177 (w). UV/Vis $\left(\mathrm{CH}_{2} \mathrm{Cl}_{2}\right)$ : no maxima observed. MS (FAB): $m / z(\%): 761(5)\left[\mathrm{M}^{+}-\mathrm{OSO}_{2} \mathrm{CF}_{3}\right], 595(100)$ [761-2 $\left.\mathrm{CNC}\left(\mathrm{CH}_{3}\right)_{3}\right], 529(10)\left[761-\mathrm{OSO}_{2} \mathrm{CF}_{3}-\mathrm{CNC}\left(\mathrm{CH}_{3}\right)_{3}\right], 446(63)$ [529- $\left.\mathrm{CNC}\left(\mathrm{CH}_{3}\right)_{3}\right] . \mathrm{C}_{38} \mathrm{H}_{40} \mathrm{~F}_{6} \mathrm{FeN}_{6} \mathrm{O}_{6} \mathrm{~S}_{2}$ (910.79): calcd. C 50.11, H 4.43, N 9.23; found C 50.29, H 4.60, N 9.27 (\%).

Bis(trifluoromethanesulfonato $)\left[N, N^{\prime}-\left(6,6^{\prime}\right.\right.$-dimethylbiphenyl-2,2' diyl)bis(2-pyridylmethyl)diimine]iron(II): A solution of AgOTf ( $289 \mathrm{mg}, 1.12 \mathrm{mmol})$ in THF $(15 \mathrm{~mL})$ was added to complex 8 $(0.55 \mathrm{mmol})$ suspended in THF $(15 \mathrm{~mL})$. After stirring overnight, 
Table 6. Details of crystal structure determinations

\begin{tabular}{|c|c|c|c|}
\hline & 8 & 11 & $14^{[a]}$ \\
\hline Empirical formula & $\mathrm{C}_{26} \mathrm{H}_{22} \mathrm{Cl}_{2} \mathrm{FeN}_{4}$ & $\mathrm{C}_{26} \mathrm{H}_{22} \mathrm{Cl}_{2} \mathrm{CoN}_{4}$ & {$\left[\mathrm{C}_{36} \mathrm{H}_{40} \mathrm{~N}_{6} \mathrm{Fe}\right]\left[\mathrm{CF}_{3} \mathrm{O}_{3} \mathrm{~S}\right]_{2} \cdot \mathrm{C}_{7} \mathrm{H}_{8}$} \\
\hline CCDC number ${ }^{[\mathrm{b}]}$ & 229184 & 229186 & 229185 \\
\hline$M w(\mathrm{~g} / \mathrm{mol}) ; F(000)$ & $517.23 ; 1064$ & $520.31 ; 1068$ & $1002.77 ; 1040$ \\
\hline Crystal color and form & blue plate & red prism & red prism \\
\hline Crystal size (mm) & $0.5 \times 0.3 \times 0.3$ & $0.5 \times 0.5 \times 0.4$ & $0.4 \times 0.4 \times 0.3$ \\
\hline$T(\mathrm{~K}) ; d_{\text {calcd }}\left(\mathrm{g} / \mathrm{cm}^{3}\right)$ & $243 ; 1.380$ & $238 ; 0.933$ & $243 ; 1.351$ \\
\hline Crystal system & monoclinic & monoclinic & triclinic \\
\hline Space group & $\mathrm{C} 2 / \mathrm{c}$ & $C 2 / c$ & $P-1$ \\
\hline Unit cell: $a[\AA]$ & $14.598(4)$ & $14.396(2)$ & $12.564(7)$ \\
\hline$b[\AA]$ & $10.657(2)$ & $10.6835(15)$ & $13.497(6)$ \\
\hline$c[\AA]$ & $17.304(6)$ & $17.3013(18)$ & $15.876(8)$ \\
\hline$\alpha\left[^{\circ}\right]$ & 90 & 90 & $97.95(3)$ \\
\hline$\beta\left[^{\circ}\right]$ & $112.40(3)$ & $111.955(7)$ & $101.67(5)$ \\
\hline$y\left[{ }^{\circ}\right]$ & 90 & 90 & $106.93(3)$ \\
\hline$V\left[\AA^{3}\right] ; Z$ & $2488.8(11) ; 4$ & $2468.0(6) ; 4$ & $2465.9(22) ; 2$ \\
\hline$\theta$ range $\left[{ }^{\circ}\right]$ & $2.44-25.00$ & $2.44-26.99$ & $1.34-25.00$ \\
\hline Reflections: collected & 2375 & 3262 & 9284 \\
\hline independent & 1874 & 2700 & 7860 \\
\hline$R_{\text {int }}$ & $4.90 \%$ & $1.67 \%$ & $6.12 \%$ \\
\hline$\mu\left(\mathrm{mm}^{-1}\right)$; absorption corr. & $0.842 ; \psi-$ scan & $0.933 ; \psi$-scan & $0.464 ; \psi$-scan \\
\hline$R 1(F) ; w R\left(F^{2}\right)[I>2 \sigma(I)]$ & $5.54 \% ; 12.44 \%$ & $3.39 \% ; 8.31 \%$ & $7.19 \% ; 18.57 \%$ \\
\hline$R 1(F) ; w R\left(F^{2}\right)$ (all data) & $8.55 \% ; 13.98 \%$ & $4.30 \% ; 8.79 \%$ & $11.57 \% ; 23.16 \%$ \\
\hline$G o F\left(F^{2}\right)$ & 1.086 & 1.052 & 1.051 \\
\hline Residual electron density & $0.406 \mathrm{e}^{-\cdot} \cdot \AA^{-3}$ & $0.352 \mathrm{e}^{-\cdot} \cdot \AA^{-3}$ & $0.644 \mathrm{e}^{-} \cdot \AA^{-3}$ \\
\hline
\end{tabular}

[a] One disordered triflate anion was refined with geometrical restraints applied; occupation factors were refined to 0.66 and 0.34 , respectively. [b] CCDC-229184 to -229186 contain the supplementary crystallographic data for this paper. These data can be obtained free of charge from The Cambridge Crystallographic Data Centre via www.ccdc.cam.ac.uk/data_request/cif.

the solvent was evaporated to dryness and the residue extracted with $\mathrm{CH}_{2} \mathrm{Cl}_{2}(6 \times 40 \mathrm{~mL})$. The combined extracts were evaporated to dryness, the solids suspended in diethyl ether $(20 \mathrm{~mL})$, collected by filtration and washed with diethyl ether $(10 \mathrm{~mL})$. Yield $318 \mathrm{mg}$ (427 $\mu \mathrm{mol}, 76 \%)$ of violet product. ${ }^{1} \mathrm{H} \mathrm{NMR}\left(250 \mathrm{MHz}, \mathrm{CDCl}_{3}\right)$ : no signals detected. IR $\left(\mathrm{KBr}, \mathrm{cm}^{-1}\right): \tilde{v}=3109,3084,3062,3034$ (m, w, m, w, Ar-H), 2963, 2928, 2854 (m, m, w, C-H), 1640, 1602, $1571(\mathrm{~s}, \mathrm{~s}, \mathrm{~m}, \mathrm{C}=\mathrm{N}, \mathrm{C}=\mathrm{C}), 1477,1453\left(\mathrm{~m}, \mathrm{~s}, \mathrm{C}-\mathrm{H}_{\text {def }}\right), 1315,1306$, $1237,1220,1184,1172,1158$ (s, m, s, s, s, m, s, S=O, C-F), 1029 (s), $1016(\mathrm{~s}), 780(\mathrm{~s}), 628(\mathrm{~s}) . \mathrm{IR}\left(\mathrm{PE}, \mathrm{cm}^{-1}\right): \tilde{\mathrm{v}}=584(\mathrm{~s}), 571(\mathrm{~m})$, $558(\mathrm{~m}), 515(\mathrm{~s}), 473(\mathrm{~m}), 435(\mathrm{~m}), 418(\mathrm{~s}), 358(\mathrm{~m}), 349(\mathrm{w}), 336$ (m), $315(\mathrm{~m}), 292(\mathrm{~s}), 249(\mathrm{~m}), 235(\mathrm{~m}), 212(\mathrm{~m}), 187(\mathrm{~m}), 171(\mathrm{~m})$, 139 (w), 123 (w). UV/Vis $\left(\mathrm{CH}_{2} \mathrm{Cl}_{2}\right): \lambda_{\max }=492 . \mathrm{C}_{28} \mathrm{H}_{22} \mathrm{~F}_{6} \mathrm{FeN}_{4} \mathrm{O}_{6} \mathrm{~S}_{2}$ (744.48): calcd. C 45.17, H 2.98, N 7.53; found C 45.37, H 3.31, N $7.53(\%)$. For crystal structure data see CCSD no 229183.

Dichloro[ $N, N^{\prime}$ - $\left(6,6^{\prime}\right.$-dimethylbiphenyl-2,2 -diyl)bis(2-pyridylmethyl)diimine]iron(III) chloride $\cdot \mathrm{CH}_{2} \mathrm{Cl}_{2}\left(\mathbf{8 C l} \cdot \mathrm{CH}_{2} \mathrm{Cl}_{2}\right)$ : A solution of ligand $2(894 \mathrm{mg}, 2.29 \mathrm{mmol})$ in THF $(20 \mathrm{~mL})$ was added to $\mathrm{FeCl}_{3}$ (364 mg, $2.24 \mathrm{mmol})$ in THF ( $30 \mathrm{~mL}$ ). After stirring overnight, the solution was evaporated to dryness, the residue dissolved in $\mathrm{CH}_{2} \mathrm{Cl}_{2}$ $(20 \mathrm{~mL})$, filtered via cannula, and the solvent removed by evaporation again. The solid residue was suspended in diethyl ether $(20 \mathrm{~mL})$, collected by filtration, washed with diethyl ether $(3 \times 10 \mathrm{~mL})$ and dried in vacuo. Yield $865 \mathrm{mg}(1.36 \mathrm{mmol}, 61 \%)$ of dark violet $8 \mathrm{Cl} \cdot \mathrm{CH}_{2} \mathrm{Cl}_{2}$. SQUID: $\mu_{\mathrm{eff}}=6.69 \mu_{\mathrm{B}} \cdot{ }^{1} \mathrm{H} \mathrm{NMR}$ $\left(250 \mathrm{MHz}, \mathrm{CDCl}_{3}\right)$ : no signals detected. IR $\left(\mathrm{KBr}, \mathrm{cm}^{-1}\right): \tilde{v}=3062$, 3014 (m, m, Ar-H), 2964, 2924, 2863 (m, w, m, C-H), 1631, 1595, $1567(\mathrm{~m}, \mathrm{~s}, \mathrm{~m}, \mathrm{C}=\mathrm{N}, \mathrm{C}=\mathrm{C}), 1467,1449\left(\mathrm{~m}, \mathrm{~s}, \mathrm{C}-\mathrm{H}_{\text {def }}\right), 1017$ (s). IR $\left(\mathrm{PE}, \mathrm{cm}^{-1}\right): \tilde{v}=591(\mathrm{~m}), 557(\mathrm{~m}), 518(\mathrm{~m}), 483(\mathrm{~m}), 460(\mathrm{~m}), 416$ (w), $379(\mathrm{~s}), 331(\mathrm{w}), 278(\mathrm{~m}), 236(\mathrm{~m}), 136(\mathrm{~m})$. UV/Vis $\left(\mathrm{CH}_{2} \mathrm{Cl}_{2}\right)$ : $\lambda_{\max }(\varepsilon)=591(1980)$. MS (FAB): $m / z(\%): 483 / 481(64 / 33)\left[\mathrm{M}^{+}-\right.$ $\mathrm{CH}_{2} \mathrm{Cl}_{2}-2 \mathrm{Cl}$ ], 446 (93) [481/483- Cl], $391(100)$ [446- $\mathrm{Fe}+\mathrm{H}$ ]. $\mathrm{C}_{27} \mathrm{H}_{24} \mathrm{Cl}_{5} \mathrm{FeN}_{4}$ (637.63): calcd. C 50.86, H 3.79, N 8.79; found $\mathrm{C}$ $50.87, \mathrm{H} 3.94, \mathrm{~N} 8.88(\%)$.
Diffractometric Structure Determination: Diffraction data for complexes $8, \mathbf{1 1}$, and 14 were collected on a Siemens P4 diffractometer by using graphite-monochromatized Mo- $K \alpha$ radiation with $\lambda=$ $0.71073 \AA$ (Table 6). Three check reflections were measured every 97 reflections. The structures were solved by direct methods (SHELXS97). ${ }^{[25]}$ All non-hydrogen atoms were refined based on $F_{\text {obs }}{ }^{2}$ (SHELXL97), ${ }^{[25]}$ while hydrogen atoms were refined on calculated positions with fixed isotropic $U$, using riding model techniques.

Supporting Information: Far-infrared spectra of compounds 2, 8, 9, 12 , and $12 \mathrm{~b}$, temperature dependence of paramagnetic NMR shifts for complex 8, GPC elution diagrams of polyethene samples obtained from entries $9-11$ in Table 5 .

\section{Acknowledgments}

For contributions to this work at the University of Konstanz we thank Anke Friemel (for 2D NMR spectra), Marie-Jose Quelle and Klaus Hägele (for EI and FAB mass spectra) and Dirk Haffke (for elemental analyses). For helpful comments we thank Professor U1rich Steiner, for diffractometric structure determinations Dr. Ulrich Wieser (both University of Konstanz) and Dr. Christian Eichhorn (University of Würzburg). Encouragement for this work byProfessor Wolf-Dieter Schenk (University of Würzburg) and by Professor Markku Leskälä (University of Helsinki) and financial support by BMBF and BASELL GmbH are gratefully acknowledged.

[1] a) L. K. Johnson, C. M. Killian, M. Brookhart, J. Am. Chem. Soc. 1995, 117, 6414-6415; b) B. L. Small, M. Brookhart, A. M. A. Bennett, J. Am. Chem. Soc. 1998, 120, 4049-4050; c) S. D. Ittel, L. K. Johnson, M. Brookhart, Chem. Rev. 2000, 100, 1169-1203.

[2] a) G. J. P. Britovsek, V. C. Gibson, B. S. Kimberley, P. J. Maddox, S. J. McTavish, G. A. Solan, A. J. P. White, D. J. Williams, 
Chem. Commun. 1998, 849-850; b) G. J. P. Britovsek, V. C. Gibson, D. F. Waas, Angew. Chem. 1999, 111, 448-468; Angew. Chem. Int. Ed. 1999, 38, 428 447; c) G. J. P. Britovsek, M. Bruce, V. C. Gibson, B. S. Kimberley, P. J. Maddox, S. Mastroianni, S. J. McTavish, C. Redshaw, G. A. Solan, S. Strömberg, A. J. P. White, D. J. Williams, J. Am. Chem. Soc. 1999, 121, 8728-8740; d) V. C. Gibson, S. K. Spitzmesser, Chem. Rev. $2003,103,283-316$.

[3] a) L. K. Johnson, S. Mecking, M. Brookhart, J. Am. Chem. Soc. 1996, 118, 267-268; b) S. Mecking, Angew. Chem. 2001, 113, 550-557; Angew. Chem. Int. Ed. 2001, 40, 534-540; c) L. S. Boffa, B. M. Novak, Chem. Rev. 2000, 100, 1479-1494.

[4] L. Resconi, L. Cavallo, A. Fait, F. Piemontesi, Chem. Rev. 2000, 100, 1253-1346.

[5] a) C. Pellecchia, A. Zambelli, Macromol. Rapid Commun. 1996, 17, 333-338; b) C. Pellecchia, M. Mazzeo, D. Pappalardo, Macromol. Rapid Commun. 1998, 19, 651-655; c) B. L. Small, M. Brookhart, Macromolecules 1999, 32, 2120-2132.

[6] a) A. Togni, L. M. Venanzi, Angew. Chem. 1994, 106, 517-547; Angew. Chem. Int. Ed. Engl. 1994, 33, 497-527; b) F. Fache, E. Schulz, M. L. Tommasino, M. Lemaire, Chem. Rev. 2000, 100, 2159-2231.

[7] a) W. B. Smith, J. Heterocycl. Chem. 1987, 24, 745-748; b) S. Flanagan, J. Dong, K. Haller, S. Wang, W. R. Scheidt, R. A. Scott, T. R. Webb, D. M. Stanbury, L. J. Wilson, J. Am. Chem. Soc. 1997, 119, 8857-8868; c) H. Suda, S. Kanoh, N. Murose, S. Goka, M. Motoi, Polym. Bull. 1983, 10, 162-167.

[8] Complex 8 was also prepared from $\mathrm{FeCl}_{2} \cdot 4 \mathrm{H}_{2} \mathrm{O}$, but approximately one equivalent of water remained in the product, as judged by its elemental analysis and IR spectrum.

[9] a) F. H. Allen, Acta Crystallogr., Sect. B 2002, 58, 380-388; b) I. J. Bruno, J. C. Cole, P. R. Edington, M. Kessler, C. F. Macrae, P. McCabe, J. Pearson, R. Taylor, Acta Crystallogr., Sect. B 2002, 58, 389-397.

[10] a) D. A. Buckingham, F. P. Dwyer, H. A. Goodwin, A. M. Sargeson, Austr. J. Chem. 1964, 17,325-336; b) P. Spacu, M. Teodorescu, C. I. Lepadatu, Z. Phys. Chem. (Muenchen Ger.) 1974, 88, 285-289; c) T. J. Hubin, J. M. McCormick, S. R. Collinson, M. Buchalova, C. M. Perkins, N. W. Alcock, P. K. Kahol, A. Raghunathab, D. H. Busch, J. Am. Chem. Soc. 2000, $122,2512-2522$

[11] a) G. La Mar, J. S. de Ropp, in: NMR of Paramagnetic Molecules (Eds.: L. J. Berliner, J. Reuben), Plenum Press, New York, 1993, p. 1-73; b) I. Bertini, C. Luchinat, Coord. Chem. Rev. 1996, 150, 77-110; c) T. E. Lehmann, L.-J. Ming, M. E. Rosen, L. Que, Jr., Biochemistry 1997, 36, 2807-2816.

[12] K. Nakamoto, Infrared and Raman Spectra of Inorganic and Coordination Compounds, Part B: Applications in Coordination, Organometallic, and Bioinorganic Chemistry, $5^{\text {th }}$ ed., John Wiley \& Sons, Inc., New York, 1997, p. 23-30, 183-190.

[13] The Fe-N vibration of 8 at ca. $223 \mathrm{~cm}^{-1}$ is probably obscured by the broad and intense peak at $244 \mathrm{~cm}^{-1}$.

[14] When brown 12 or 12.THF was stirred overnight in an apolar solvent such as toluene or diethyl ether, it was transformed to a pink-colored solid (12b). Stirring $\mathbf{1 2 b}$ in THF or $\mathrm{CH}_{2} \mathrm{Cl}_{2}$ regenerates brown 12. Complex 12b has a high-spin value of $\mu_{\mathrm{eff}}=5.23 \mu_{\mathrm{B}}$. Formation of $\mathbf{1 2 b}$ in non-polar solvents indicates that both chloride ligands are coordinated, but $\mathbf{1 2 b}$ differs from the $C_{2}$-symmetric complexes $\mathbf{7 - 1 1}$ in its FIR bands at 327 (s), $269(\mathrm{~m})$ and $202(\mathrm{~m}) \mathrm{cm}^{-1}$. In the absence of suitable single crystals, its coordination geometry cannot be reliably assigned.

[15] a) J. J. Zuckermann, J. Chem. Educ. 1965, 42, 315-317; b) R. Krishnamurthy, W. B. Schaap, J. Chem. Educ. 1969, 46, 799 810.

[16] We were not able to obtain satisfactory elemental analyses for complex 13. Although no other species were detected in its NMR spectra, elemental analysis consistently gave carbon values too low by $3-4 \%$; this might be caused by the presence of small amounts of $\mathrm{MgCl}_{2}$

[17] Reactions of 8 with 2 equiv. of silver triflate gave the analytically pure bistriflate derivative (see Exp. Sect.). A diffractometric structure determination revealed a $C_{2}$-symmetric geometry rather similar to that of $\mathbf{8}$ (for details see CCDC229183).

[18] Vibrations of the isocyanide ligands were observed at 2160 and $2184 \mathrm{~cm}^{-1}$, significantly higher than $v_{\mathrm{CN}}=2138 \mathrm{~cm}^{-1}$ measured for free isocyanide. Back-bonding from the metal to the isocyanide ligand thus appears negligible.

[19] Coordination of both $\sigma$-donors trans to pyridine is prohibited by the obligatory cis-coordination of the diimine nitrogen atoms.

[20] a) H. K. Gupta, S. Brydges, M. J. McGlinchey, Organometallics $1999,18,115-122$; b) V. C. Gibson, P. J. Maddox, C. Newton, C. Redshaw, G. A. Solan, A. J. P. White, D. J. Williams, Chem. Commun. 1998, 1651-1652.

[21] Further propene polymerization experiments with 8/MAO, 12/ $\mathrm{MAO}$, or $13 / \mathrm{MAO}$ in $\mathrm{CH}_{2} \mathrm{Cl}_{2}$ or toluene, at temperatures between 40 and $80^{\circ} \mathrm{C}$, propene pressures ranging from 2 to 10 bar and polymerization times up to 23 hours failed in all cases to produce even traces of polypropene.

[22] We assume that the unexpected formation of $60 \mathrm{mg}$ of polyethene in polymerization run no. 2 (and in occasional other polymerization experiments) is caused by incomplete homogeneous dispersion of $\mathbf{8}$ due to insufficient exposure to the ultrasound pretreatment.

[23] H.-K. Luo, Z.-H. Yang, B.-Q. Mao, D.-S. Yu, R. G. Tang, $J$. Mol. Catalysis A: Chem. 2002, 177, 195; K. P. Bryliakov, N. V. Semikolenova, V. N. Zudin, V. A. Zakharov, E. P. Talsi, Catal. Commun. 2004, 5, 45-48.

[24] M. Kettunen, C. Vedder, F. Schaper, M. Leskelä, I. Mutikainen, H.-H. Brintzinger, Organometallics 2004, 23, 3800 3807.

[25] a) G. M. Sheldrick, SHELXS97, Program for the Solution of Crystal Structures, University of Göttingen, Göttingen, Germany, 1997; b) G. M. Sheldrick, SHELXL97, Program for Crystal Structure Refinement, University of Göttingen, Göttingen, Germany, 1997. 